\title{
Studies of Cystoseira assemblages in Northern Atlantic Iberia
}

\author{
Alicia García-Fernández* \& Ignacio Bárbara \\ Departamento de Biología Animal, Biología Vegetal y Ecología, Facultad de Ciencias, \\ Universidad de La Coruña, Campus de A Zapateira, 15071 La Coruña, \\ Spain. alicia.garcia.fernandez@udc.es, barbara@udc.es
}

\begin{abstract}
García-Fernández, A. \& Bárbara, I. 2016. Studies of Cystoseira assemblages in Northern Atlantic Iberia. Anales Jard. Bot. Madrid 73(1): e035.

The Iberian Peninsula contains 24 specific and infraespecific taxa of the genus Cystoseira, but only 6 inhabit in Northern Iberia: C. baccata, C. foeniculacea, C. humilis var. myriophylloides, C. nodicaulis, C. tamariscifolia, and C. usneoides. The Cystoseira assemblages exhibit a complex structure and stratification that allows the presence of a large associate biota and a rich epiphytic flora. Although in the Mediterranean Sea several species have been analyzed in depth, the Atlantic ones are less studied. A revision of the literature (1931-2014) and grey information was made to know the diversity of the North Atlantic Iberian Cystoseira assemblages. The community of C. baccata harbors the biggest number of species (215), followed by C. tamariscifolia (162) and C. usneoides (126), whereas the community with fewest species was the $C$. foeniculacea one (34). More than 70 species were present in the majority of the Cystoseira assemblages. In this article, are revised also environmental issues in the Cystoseira assemblages, as pollution and anthropogenic pressures or disturbances that cause regression in their communities, and effects of biological invasions by non-native species. As a conclusion, it will necessary to study the Cystoseira assemblage in depth, starting by research of $C$. baccata along Northern Iberia, as it is an exclusive and widely distributed Atlantic species with very scarce information concerning its role in structuring the communities.
\end{abstract}

Key words: biodiversity, Cystoseira, Iberian Peninsula, marine assemblages, seaweeds.

\section{DIVERSITY AND DISTRIBUTION OF THE GENUS CYSTOSEIRA}

The genus Cystoseira C. Agardh was described in 1820, including 37 species, although its taxonomy and nomenclature has suffered many changes since then, because of variability within the genus occurs not only among species but also among individuals of a single species and, seasonally, within a single individual. Moreover, in some species, no holotype was designated in species description, and lectotypes have yet to be chosen (Furnari \& al., 1999). To complete the knowledge of Cystoseira (taxonomy and evolutionary origin), Draisma \& al. (2010) made a phylogenetic analysis of the Sargassaceae and found out that Bifurcaria, Cystoseira, Halidrys, and Sargassum (as currently recognized) are polyphyletic and should each be split into two or more genera. The genus Cystoseira was originated in the Thetis Sea during the Mesozoic, afterwards, some species stayed in the Indo-Pacific Ocean and others should have entered into the Mediterranean Sea from the Atlantic Ocean during the

\section{Resumen}

García-Fernández, A. \& Bárbara, I. 2016. Estudios acerca de los agregados de Cystoseira de las costas atlánticas del norte de la Península Ibérica. Anales Jard. Bot. Madrid 73(1): e035.

La Península Ibérica contiene 24 táxones del género Cystoseira, pero sólo 6 habitan en las costas del norte: C. baccata, C. foeniculacea, C. humilis var. myriophylloides, C. nodicaulis, C. tamariscifolia y C. usneoides. Las comunidades de Cystoseira muestran una estructura compleja debido a su estratificación, lo que permite el desarrollo de una amplia biota asociada y una gran riqueza de flora epífita. Aunque diversas especies mediterráneas han sido analizadas en profundidad, las atlánticas son menos conocidas. Se ha recopilado información bibliográfica (1931-2014) y datos inéditos para conocer la diversidad de las comunidades de Cystoseira en las costas atlánticas del norte de la Península Ibérica. Las comunidades de $C$. baccata albergan el mayor número de especies (215), seguido de C. tamariscifolia (162) y C. usneoides (126), mientras que la comunidad con el menor número de especies fue $C$. foeniculacea (34). Más de 70 especies están presentes en la mayoría de las comunidades de Cystoseira. En este artículo, se han revisado también aspectos medioambientales que afectan a las comunidades de Cystoseira, como contaminación y perturbaciones antropogénicas que causan la regresión de las poblaciones, así como los efectos de las invasiones biológicas por especies alóctonas. Como conclusión, será necesario el estudio de las comunidades de Cystoseira en profundidad, empezando por investigaciones de C. baccata en el norte, ya que es una especie exclusiva y ampliamente distribuida en el Atlántico y con escasa información relativa a su papel en la estructuración de comunidades.

Palabras clave: algas, biodiversidad, comunidades marinas, Cystoseira, Península Ibérica.

Cenozoic, starting a speciation process that continues nowadays (Oliveras Plá \& Gómez Garreta, 1989).

According to the literature (Gómez Garreta \& al., 2000; Cormaci \& al., 2012) Cystoseira species are plants about 1 meter high with a single primary axis or several primary axes in caespitose thalli, attached to the substratum by a conical disc or haptera. Its apex is smooth or spinous and its ramification in branches is abundant, radial or distichous, sometimes with small spine-like or filiform appendages. These branches could exhibit a characteristic greenish-blue iridescence. Some species present conical or ovoid tophules, arranged along the axis or grouped in the apical zone; and aerocysts, isolated or arranged in chains at the apices of the terminal branchlets. Receptacles are developed usually at the upper parts of higher order branchlets, but they are variable in shape, sometimes bifurcate or branched and with spine-like appendages. Conceptacles are generally hermaphrodite, although they can be unisexual at least during some periods of the year. Cryptostomata are present in most species, normally sunk into the branchlets and, only occasionally, pedicellate. 
Table 1. Iberian Cystoseira species and their distribution (Ribera \& al., 1992; Gómez Garreta \& al., 2000; Rodríguez-Prieto \& al., 2013).

\begin{tabular}{|c|c|c|}
\hline Taxa & Mediterranean Iberia & Atlantic Iberia \\
\hline C. abies-marina (S.G. Gmelin) C. Agardh & + & \\
\hline C. algeriensis Feldmann & + & \\
\hline C. amentacea var. stricta Montagne & + & \\
\hline C. baccata (S.G. Gmelin) P.C. Silva & & + \\
\hline C. barbata (Stackhouse) C. Agardh & + & \\
\hline C. barbata f. repens A.D. Zinova \& Kalugina & + & + \\
\hline C. barbatula Kützing & + & \\
\hline C. brachycarpa Sauvageau & + & \\
\hline C. brachycarpa var. claudiae (Giaccone) Giaccone & + & \\
\hline C. compressa (Esper) Gerloff \& Nizamuddin & + & + \\
\hline C. compressa f. plana (Ercegovic) M. Cormaci \& al. & + & \\
\hline C. crinita Duby & + & \\
\hline C. elegans Sauvageau & + & \\
\hline C. foeniculacea (L.L.) Greville & + & + \\
\hline C. foeniculacea f. latiramosa (Ercegovic) A. Gómez Garreta \& al. & + & \\
\hline C. foeniculacea f. tenuiramosa (Ercegovic) A. Gómez Garreta \& al. & + & \\
\hline C. funkii Schiffner ex Gerloff \& Nizamuddin & + & \\
\hline C. humilis Schoubsboe ex Kützing & + & + \\
\hline C. humilis var. myriophylloides (Sauvageau) J.H. Price \& D.M. John & & + \\
\hline C. mauritanica Sauvageau & + & \\
\hline C. mediterranea Sauvageau & + & \\
\hline C. nodicaulis (Withering) M. Roberts & + & + \\
\hline C. pelagosae Ercegovic & + & \\
\hline C. sauvageauana Hamel & + & + \\
\hline C. sedoides (Desf.) C. Agardh & + & \\
\hline C. spinosa Sauvageau & + & \\
\hline C. spinosa var. compressa (Ercegovic) M. Cormaci \& al. & + & + \\
\hline C. spinosa var. tenuior (Ercegovic) M. Cormaci \& al. & + & \\
\hline C. squarrosa De Notaris & + & \\
\hline C. tamariscifolia (Hudson) Papenfuss & + & + \\
\hline C. usneoides (L.) M. Roberts & + & + \\
\hline C. zosteroides C. Agardh & + & \\
\hline
\end{tabular}

Among the 51 specific and infraespecific taxa of Cystoseira (Guiry \& Guiry, 2014; Thibaut \& al., 2014), 36 are present in the Mediterranean Sea, and 30 are endemic of this Sea. The Iberian Peninsula contains 24 species (31 taxa, table 1) and 14 taxa are exclusive of the Mediterranean Sea, 1 taxa of the Atlantic Ocean, and 9 taxa are present in both, Mediterranean Sea and Atlantic Ocean. In Northern Iberian coasts (table 2, figs. 1-2) inhabit 6 specific and infraespecific taxa: C. baccata, C. foeniculacea, C. humilis var. myriophylloides, C. nodicaulis, C. tamariscifolia, and C. usneoides. The diversity of the genus Cystoseira is relevant and necessary to protect and manage of their populations, but at present, it has been studied unevenly between regions and issues. Thus, although several species in the Mediterranean Sea have been analyzed in depth (morphology, taxonomy, diversity, assemblages, etc.), the Atlantic ones are less studied, especially in Northern Iberian Peninsula.

\section{THE CYSTOSEIRA ASSEMBLAGES}

The assemblages of Cystoseira exhibit a complex structure, which allows the presence of a large number of vegetal and animal companion species. Moreover, assemblages dominated by Cystoseira species rank amongst the most productive in the Mediterranean and provide habitat for a considerable number of other algae and invertebrate species (Furnari, 1997; Belegratis \& al., 1999; Pardi \& al., 2000; Montesanto \& Panayotidis, 2001; Sales \& Ballesteros, 2007, 2009, 2012; Sales \& al., 2012). Following Ballesteros (1989), the benthic production is of great importance in littoral ecosystem dynamics as it represents an input of energy and organic matter that, on a small scale, being higher than the phytoplankton's contribution. Moreover, the production increases from the upper mediolittoral zone to the shallow Cystoseira communities and, downwards, it gradually decreases with 
Table 2. North Atlantic Iberian species of Cystoseira and their features (Roberts, 1967; Ardré, 1970; Bárbara \& Cremades, 1987, Bárbara, 1994; Otero-Schmitt \& Pérez-Cirera, 1996; Cremades \& al., 1998; Gómez Garreta \& al., 2000; Otero \& al., 2002; Llera González \& Álvarez Raboso, 2007).

\begin{tabular}{|c|c|c|c|c|c|c|}
\hline & C. baccata & C. foeniculacea & $\begin{array}{l}\text { C. humilis var. } \\
\text { myriophylloides }\end{array}$ & C. nodicaulis & C. tamariscifolia & C. usneoides \\
\hline Attachment & Conical disc & Disc with several axes & Compact disc & Conical disc & $\begin{array}{l}\text { Disc or haptera } \\
\text { thick and } \\
\text { branched }\end{array}$ & $\begin{array}{l}\text { Haptera that } \\
\text { usually do not } \\
\text { form a disc }\end{array}$ \\
\hline Axis & $\begin{array}{l}\text { Flattened to } \\
\text { terete. Axis single } \\
\text { (not caespitose) }\end{array}$ & $\begin{array}{l}\text { Terete. Several axes } \\
\text { (caespitose).covered } \\
\text { with spines }\end{array}$ & $\begin{array}{l}\text { Terete. Several } \\
\text { axes (caespitose). } \\
\text { Basal appendages }\end{array}$ & $\begin{array}{l}\text { Terete, single } \\
\text { (not caespitose). } \\
\text { Branched. With } \\
\text { tubers at the basis }\end{array}$ & $\begin{array}{l}\text { Terete, single (not } \\
\text { caespitose). Often } \\
\text { branched }\end{array}$ & $\begin{array}{l}\text { Terete, single } \\
\text { (not caespitose). } \\
\text { Branched }\end{array}$ \\
\hline Apex & $\begin{array}{l}\text { Smooth. } \\
\text { Prominent }\end{array}$ & Not very prominent & $\begin{array}{l}\text { Smooth. Slightly } \\
\text { prominent }\end{array}$ & Smooth. Prominent & $\begin{array}{l}\text { Not very } \\
\text { prominent. } \\
\text { Covered by small } \\
\text { spines }\end{array}$ & $\begin{array}{l}\text { Smooth. Not very } \\
\text { prominent }\end{array}$ \\
\hline Branches & $\begin{array}{l}\text { Compressed. } \\
\text { Distichous }\end{array}$ & $\begin{array}{l}\text { Cylindrical. Alternated } \\
\text { and distich }\end{array}$ & Well-developed & $\begin{array}{l}\text { Pinnate. With } \\
\text { spinous appendages }\end{array}$ & $\begin{array}{l}\text { Cylindrical. } \\
\text { Profusely } \\
\text { branched. } \\
\text { Covered by } \\
\text { numerous spinous } \\
\text { appendages }\end{array}$ & $\begin{array}{l}\text { Cylindrical. } \\
\text { Highest order } \\
\text { covered by } \\
\text { small filiform } \\
\text { appendage. }\end{array}$ \\
\hline $\begin{array}{l}\text { Foliaceous } \\
\text { branches }\end{array}$ & $\begin{array}{l}\text { Frequent, at the } \\
\text { base and with } \\
\text { midrib }\end{array}$ & $\begin{array}{l}\text { Occasionally, at the base } \\
\text { and with midrib }\end{array}$ & Absent & Absent & Absent & $\begin{array}{l}\text { Frequent, at the } \\
\text { base and with } \\
\text { midrib }\end{array}$ \\
\hline Tophules & Absent & Absent & Absent & $\begin{array}{l}\text { Ovoid or conical, } \\
\text { often elongated. } \\
\text { Smooth or covered } \\
\text { with small tubers }\end{array}$ & Absent & $\begin{array}{l}\text { Rugged or } \\
\text { smooth }\end{array}$ \\
\hline Aerocysts & $\begin{array}{l}\text { Elliptical, big and } \\
\text { isolated. Present } \\
\text { in the axes of } \\
\text { higher order } \\
\text { branches }\end{array}$ & $\begin{array}{l}\text { Associated with the } \\
\text { receptacles }\end{array}$ & $\begin{array}{l}\text { Short }(2-4 \mathrm{~mm}) \\
\text { at the base of } \\
\text { receptacles }\end{array}$ & $\begin{array}{l}\text { Occasionally } \\
\text { present, narrow and } \\
\text { elongated. Isolated } \\
\text { or in short chains }\end{array}$ & $\begin{array}{l}\text { Ovoid ( } 5 \mathrm{~mm} \\
\text { long) isolated or } \\
\text { in short chains }\end{array}$ & $\begin{array}{l}\text { Abundant, in } \\
\text { chains }\end{array}$ \\
\hline Iridescence & Absent & Absent & Absent & weak & $\begin{array}{l}\text { Profuse, } \\
\text { green-bluish }\end{array}$ & weak \\
\hline Receptacles & $\begin{array}{l}\text { Cylindrical (1-5 } \\
\mathrm{cm} \text { long), with } \\
\text { small filiform } \\
\text { appendages. }\end{array}$ & $\begin{array}{l}\text { Cylindrical or fusiform, } \\
\text { single or branched }\end{array}$ & $\begin{array}{l}\text { Cylindrical } \\
\text { or fusiform, } \\
\text { branched }\end{array}$ & Cylindrical. & $\begin{array}{l}\text { No compact } \\
(1-2 \mathrm{~cm} \text { long) } \\
\text { and surrounded } \\
\text { by sort spines }\end{array}$ & $\begin{array}{l}\text { Cylindrical and } \\
\text { mucronate, with } \\
\text { small spines. }\end{array}$ \\
\hline $\begin{array}{l}\text { Iberian } \\
\text { distribution }\end{array}$ & Atlantic & $\begin{array}{l}\text { Atlantic and } \\
\text { Mediterranean }\end{array}$ & $\begin{array}{l}\text { Atlantic and } \\
\text { Mediterranean }\end{array}$ & $\begin{array}{l}\text { Atlantic and } \\
\text { Mediterranean }\end{array}$ & $\begin{array}{l}\text { Atlantic and } \\
\text { Mediterranean }\end{array}$ & $\begin{array}{l}\text { Atlantic and } \\
\text { Mediterranean }\end{array}$ \\
\hline Habitat & $\begin{array}{l}\text { Lower intertidal } \\
\text { to subtidal, } \\
\text { from exposed to } \\
\text { sheltered coasts }\end{array}$ & $\begin{array}{l}\text { Lower intertidal to } \\
\text { subtidal in semiexposed } \\
\text { coasts }\end{array}$ & $\begin{array}{l}\text { Upper to middle } \\
\text { intertidal rocky } \\
\text { pools (with sandy } \\
\text { sediments), } \\
\text { from exposed } \\
\text { to semiexposed } \\
\text { coast }\end{array}$ & $\begin{array}{l}\text { Lower intertidal to } \\
\text { subtidal in sheltered } \\
\text { coasts }\end{array}$ & $\begin{array}{l}\text { Lower intertidal } \\
\text { rocky pools to } \\
\text { subtidal, from } \\
\text { exposed to } \\
\text { semiexposed } \\
\text { coast }\end{array}$ & $\begin{array}{l}\text { Typically subtidal, } \\
\text { from semiexposed } \\
\text { to sheltered } \\
\text { coasts }\end{array}$ \\
\hline
\end{tabular}

depth (Ballesteros, 1989). Numerous Mediterranean studies (Ballesteros, 1988, 1989, 1990a-b; Pardi \& al., 2000; Montesanto \& Panayotidis, 2001; Sales \& Ballesteros, 2007; 2009, 2012; Sales \& al., 2012) described the structure and dynamics of communities characterized by the Cystoseira species as they play a key role on hard substrata communities by structuring subtidal photophilic vegetation, and determining the physiognomy of the benthic vegetation. Main parameters analyzed are: community biomass, recovering percentage, specific richness, specific distribution, Molinier's point, specific diversity, patterndiversity and production.

According to Templado \& al. (2012), in Spain, the most representative Cystoseira communities are the shallow ones that form a dense band, like the C. mediterranea in Catalonia, the C. amentacea var. stricta in the Balearic Islands and the C. tamariscifolia in Alborán and the Canary Islands. In these shallow Cystoseira communities can be distinguish different strata with 50 and 300 species of flora and fauna, respectively. The upper canopy is made by the Cystoseira species with their epiphytes, like Jania rubens and Ceramium spp. The middle canopies are formed by algae as Boergeseniella fruticulosa, Polysiphonia mottei Lauret, Osmundea truncata, Ellisolandia elongata, Jania virgata (Zanardini) Montagne, Laurencia obtusa (Hudson) J.V. Lamoruroux, Anadyomene stellata (Wulfen) C. Agardh, Hypnea musciformis (Wulfen) J.V. Lamouroux, and Feldmannia caespitula (C. Agardh) Knoepffler-Péguy. The microbiotic stratum is dominated by smaller algae as Jania rubens, Cladophora laetevirens, Gelidium spp. and Chondracanthus acicularis. Finally, 

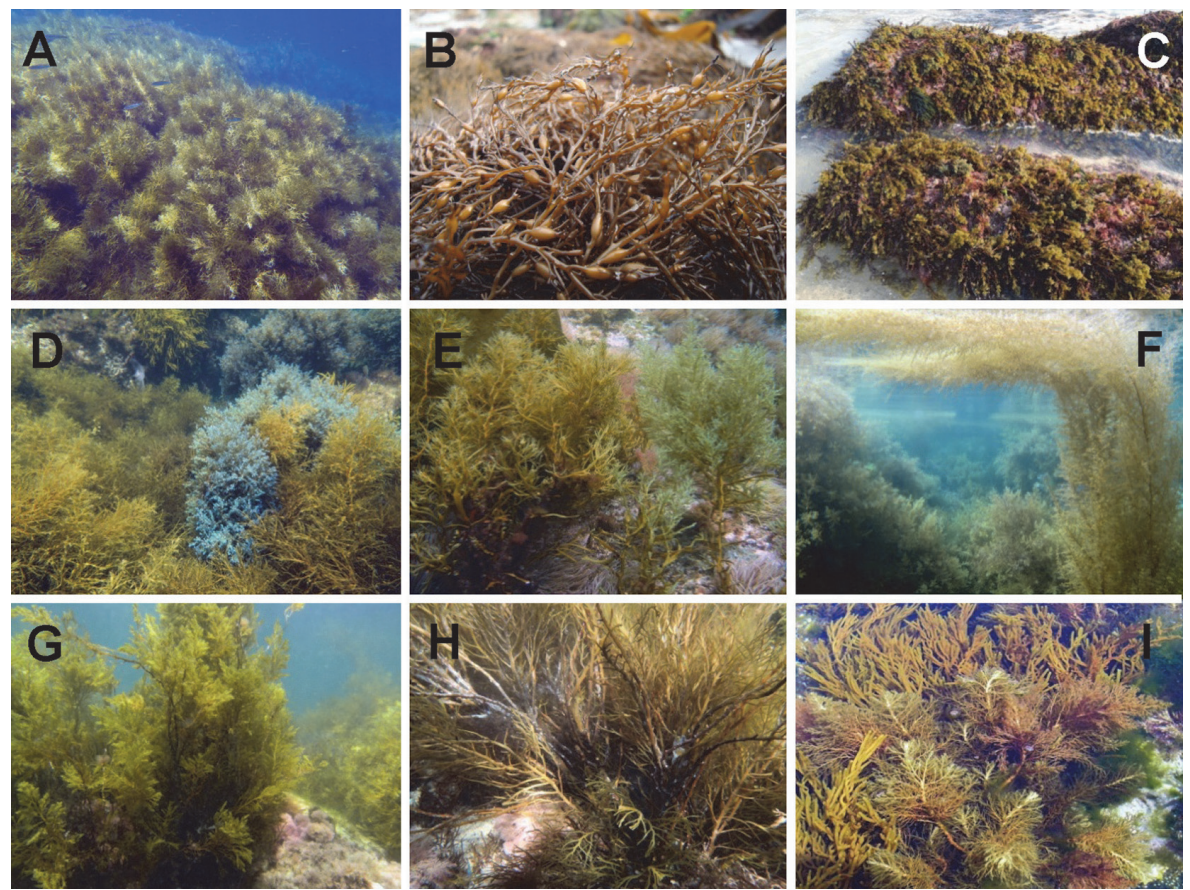

Fig. 1. Northern Atlantic Iberian species of Cystoseira: a, shallow subtidal community of C. baccata; b, detail of C. baccata and its aerocysts; c, lower intertidal community of C. baccata; d-f, subtidal C. baccata assemblages with C. tamariscifolia (d), with C. usneoides (e) and with Sargassum muticum (f); g, shallow subtidal C. foeniculacea assemblage; $\mathbf{h}$, close-up of $\mathbf{C}$. foeniculacea; $\mathbf{i}$, upper intertidal rocky pool with $\mathbf{C}$. humilis var. myriophylloides and Bifurcaria bifurcata.
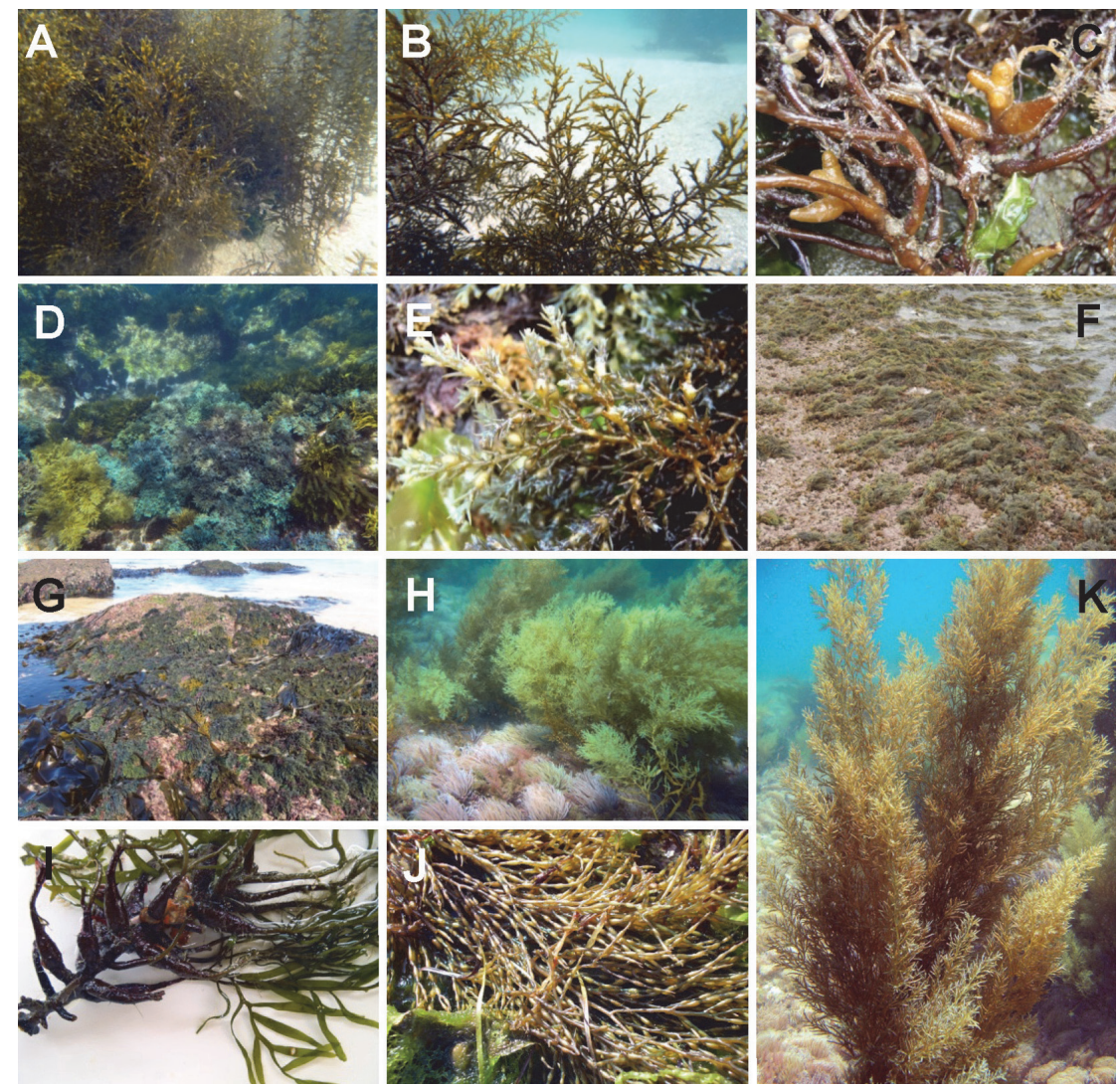

Fig. 2. Northern Atlantic Iberian species of Cystoseira: a, C. nodicaulis with Sargassum muticum in sand covered subtidal rocks; b, c, detail of C. nodicaulis with aerocysts (b) and basal tophules (c); d, shallow subtidal assemblage of $C$. tamariscifolia with C. baccata; e, detail of C. tamariscifolia and its aerocysts; $\mathbf{f}, \mathbf{g}$, lower intertidal community of $\boldsymbol{C}$. tamariscifolia; $\mathbf{h}$, subtidal community of $\boldsymbol{C}$. usneoides; $\mathbf{i}$, $\mathbf{j}$, detail of $\boldsymbol{C}$. usneoides with tophules (i) and chains of small aerocysts (j); $\mathbf{k}$, big subtidal thallus of $C$. usneoides. 
there is a calcareous strata Lithophyllum incrustans, Noegoniolithon brassica-florida (Harvey) Setchell \& L.R. Mason, Hildenbrandia crouaniorium J. Agardh, Peyssonnelia polymorpha (Zanardini) F. Schmitz, Melobesia membranacea, and Valonia utricularis (Roth) C. Agardh. In the sheltered Mediterranean coast the dominant species is C. crinita, although it can be substituted or accompanied by other Cystoseira species as C. caespitosa, C. compressa, C. foeniculacea, C. bumilis, C. barbata or C. brachycarpa var. balearica (Templado \& al., 2012).

Following the literature (Barceló i Martí \& Seoane Camba, 1984; Cormaci \& al., 1990; Ballesteros, 1990b; Ballesteros \& al., 1998; Sales \& Ballesteros, 2012; Sales \& al., 2012; Templado \& al., 2012; Thibaut \& al., 2014), on the basis of the light intensity and hydrodynamism variations, the Mediterranean marine zonation are divided in five main communities dominated by: (i) Cystoseira amentacea, in the infralittoral fringe, (ii) C. crinita, in the upper infralittoral, (iii) C. sauvageauana, in the mid-infralittoral, (iv) C. spinosa, in the lower infralittoral and (v) C. zosteroides, in the upper circalittoral zone. However, some ecological factors like temperature, sedimentation and streams can play a fundamental role in the settlement of some other communities, as C. tamariscifolia, C. barbata, C. corniculata, and C. dubia (Pardi \& al., 2000; Montesanto \& Panayotidis, 2001; Sales \& Ballesteros, 2007, 2009, 2012; Sales \& al., 2012; Templado \& al., 2012). Other Mediterranean Cystoseira species, as $C$. mediterranea and C. caespitosa, were studied by Ballesteros $(1988,1990 \mathrm{a})$ who comment that both species exhibit similar structure and composition to others wave-exposed communities dominated by Cystoseira. Apart of all these studies, Pardi \& al. (2000) affirmed that little attention has been paid to the demography of the Cystoseira genus in the Mediterranean Sea, despite this aspect is relevant for understanding the distribution and abundance of macroalgal species and hence to community structure. Because of that, Pardi \& al. (2000) studied a population of C. humilis providing the first contribution to the knowledge of its demography, assessing density, growth, reproduction, mortality, and biomass.

Although there is a basic knowledge on the habitat preferences of Cystoseira species, there are no much studies about the environmental factors affecting their distribution in the Mediterranean. In this way, Sales \& Ballesteros (2009) obtained values of 14 environmental parameters in 103 coves surveyed in Menorca Island, which were added sequentially in a model in order to predict Cystoseira assemblages' composition. They detected significant relationships between great part of the factors and Cystoseira spp. composition and abundance, what show a high predictability of Cystoseira distribution departing from environmental variables.

The Atlantic Iberian Cystoseira species typically inhabits in the subtidal forming the canopy of the community, from wave exposed to sheltered areas. Some common subtidal species are C. baccata and C. usneoides, and other such as C. bumilis inhabits from upper to middle intertidal rocky pools (Gómez Garreta \& al., 2000). In this region, according to Templado \& al. (2012) the Cystoseira species play an escort role and they could be dominant when the other species are not present. Below the C. tamariscifolia band there are present other species as C. mauritanica, C. nodicaulis, and, deeper, C. usneoides. In the Cantabrian coasts, there is a characteristic community dominated by Gelidium corneum in exposed rocks, which could be accompanied by C. baccata and other species as Mesophyllum lichenoides, Zanardinia typus, Pterosiphonia complanata, Corallina officinalis, Rhodymenia pseudopalmata, and Cryptopleura ramosa (Gorostiaga \& al., 1998; Templado \& al., 2012).

Bermejo (2014) studied the genetics of C. amentacea, C. tamariscifolia, and C. mediterranea in the south of the Iberian Peninsula and found that individuals previously identified as C. amentacea in Alboran Sea would be closer related to C. tamariscifolia from the Atlantic Ocean than to Mediterranean specimens of $C$. mediterranea or $C$. amentacea. Furthermore, the genetic patterns along southern Iberian Peninsula show an important genetic flux between Atlantic and Mediterranean populations in western and central Alboran. Therefore, the results suggest that all specimens of these three species found along Alboran Sea can be considered one specific entity, probably C. tamariscifolia, so the morphological differences observed between C. tamariscifolia and C. amentacea from southern Iberian Peninsula lack a genetic basis. Moreover, Bermejo (2014) results revealed that the highest distances occur between sites instead between groups of populations. The study of the genetic structure of threatened species with reduced dispersion such as C. tamariscifolia, which play an important role in the maintaining of the biodiversity and ecosystem functioning in littoral communities of the Mediterranean and the proximate coast of the Lusitanian provinces, could yield important information to favor the resilience of littoral communities or to develop a suitable restoration.

In Asturias, Fernández \& Niell $(1981,1982)$ studied the lower intertidal belt, dominated by Saccorbiza polyschides, Cystoseira baccata, Gelidium spp., and Mesophyllum lichenoides. The Saccorbiza-Cystoseira belt could also appear with C. tamariscifolia and other species like Chondrus crispus, Gymnogongrus crenulatus, Pterocladiella capillacea, Corallina spp., and Plocamium cartilagineum. In rocky intertidal pools of Bifurcaria bifurcata and Gelidium spinosum Fernández \& Niell $(1981,1982)$ found Dictyopteris polypodioides, C. baccata, C. tamariscifolia, Gelidium corneum, Saccorbiza polyschides, Laminaria ochroleuca, and M. lichenoides. Below to the Saccorbiza-Cystoseira belt they found a vegetation belt dominated by $C$. baccata accompanied by Ulva gigantea, Gelidium corneum, and, not so frequently, Laminaria ochroleuca and C. tamariscifolia.

In the sublittoral seaweed vegetation on the Basque coast (Gorostiaga, 1995; Díez, 1997; Gorostiaga \& al., 1998; Díez \& al., 1999; Santolaria, 2014), C. baccata is a very common species that inhabits in a wide range of depth, exposure and sedimentation conditions. Gorostiaga (1995) compared the vegetation in the shallow zone of the French Basque coast, which is very similar, although with a greater abundance of Gelidium corneum and C. tamariscifolia. Gorostiaga \& al. (1998) explains that, although the macroalgal cover was very homogeneous flostically, Plocamium cartilagineum, Pterosiphonia complanata, Asparagopsis armata, C. baccata, Halopitys incurvus, and Corallina officinalis were the most abundant macrophytes. However, under sedimentation increasing, Gelidium corneum cover decreased while the macrophytes C. baccata and Zanardinia typus become more abundant. The sedimentation was a determining factor in seaweed distribution and the main trends were: 
(i) the maximum algal cover corresponded to Gelidium corneum beds. At the same time as the sediment increased to moderate levels, the first change detected was the reduction of crustose and epiphytic layers, due to the decrease of Mesophyllum lichenoides, Plocamium cartilagineum, and Dictyota dichotoma. (ii) The most abundant species along the vegetation gradient presented patterns of distribution associated with sedimentation. Pterosiphonia complanata and C. baccata were well adapted to sedimentation, showing an optimum development at moderate to high levels. In habitats highly exposed to wave action without sediment, Pterosiphonia complanata is displaced by Gelidium corneum. In contrast, C. baccata does not tolerate heavy hydrodynamics and only competes with Gelidium corneum in semiexposed conditions.

In the North of Galicia, Anadón \& al. (1979) and Gili \& al. (1979) found that, below the horizon of Himanthalia elongata, the most important vegetation in moderately exposed or protected zones is dominated by Saccorbiza polyschides and, going down, appear a C. tamariscifolia and Boergeneniella thuyoides horizon, which is gradually substituted by Laminaria byperborea and Laminaria ochroleuca in more exposed zones. Gili \& al. (1979) described three strata in the Laminaria horizon: (i) arborescent strata, (ii) caespitose strata and (iii) incrusting strata. In deeper zones where Laminaria is scarce, they found other brown seaweeds as C. baccata, Desmarestia aculeata, Halidrys siliquosa, Carpomitra costata, Phyllariopsis brevipes, and a Dictyota sp. It could appear some red algae species, like Rodophyllis divaricata, Dilsea carnosa, and Palmaria palmata; and the green algae Ulva rigida. In the Central and South Galician coast, Granja \& al. (1992), Otero-Schmitt (1993), Bárbara (1994), Bárbara \& al. (1995), and Otero-Schmitt \& Pérez-Cirera (1996, 2002) studied subtidal populations dominated by laminarials (Laminaria ochroleuca, Laminaria byperborea, and Saccharina saccharina) and Cystoseiraceae communities (Cystoseira baccata, C. nodicaulis, and C. usneoides), which are also abundant at more sheltered and deeper areas and even on rocky and sandy bottoms. Apart from subtidal, the species of Cystoseira inhabit in the lower intertidal (Bárbara \& al., 1995, Otero-Schmitt \& Pérez-Cirera, 2002; Cremades \& al., 2004) where they form erect canopies with other big brown algae like Laminaria ochroleuca and Sargasusm muticum.

The species of Cystoseira generally supports a considerable epiphytic flora (Belegratis \& al., 1999). The epiphytes in two Mediterranean species (C. compressa and C. spinosa) were studied by Belegratis \& al. (1999) by transplanting plants to different sites. Epiphytic seasonality was generally observed in the sites, what suggests the absence of host-specific epiphytes. Moreover, the distinct zonation pattern of epiphytes covering only certain host areas was not observed. Most floristic and vegetation studies carried out on Northwestern Spain list epiphytic species, but these are not used to characterize differences among communities, as there are not much researches focused on the Cystoseira epiphytes. According to Rull Lluch \& Gómez Garreta (1989), Morales-Ayala \& Viera-Rodríguez (1989), Arrontes (1990), and Otero-Schmitt \& Pérez-Cirera (1996), an epiphytic stratification with three strata can be considered: (i) attaching discs, (ii) main axes and branches and (iii) branchlets and phylloids. However, the host plants occur in different vegetation belts and wave exposure and these factors may be more important in characterizing epiphytism on Cystoseira rather than the own structure of the host. In addition, the fall of phylloids and branchlets usually occurs in winter, causing important variations in epiphytic species that can be found in some parts of the hosts, so the perennial axes allow a more stable flora.

Otero-Schmitt \& Pérez-Cirera (1996) studied the epiphytism on four species of Cystoseira (C. baccata, C. tamariscifolia, C. humilis var. myriophylloides, and C. usneoides), that develop large and differentiated communities in the Galician coast. According to these authors, the generic specificity is small: of 125 epiphytic species, nearly half where only found on a single Cystoseira species. Rodophyta were the most abundant epiphytic group and Cyanophyta were the scarcest. Most epiphytic species were Ephemerophytes or Hypnophytes (Otero-Schmitt \& Pérez-Cirera, 1996). The cover of epiphytic species was maximal on C. tamariscifolia and C. humilis var. myriophylloides, whereas C. usneoides were much lower. The cover in C. baccata was also quite high, but less than in C. tamariscifolia. The greater number of epiphytic species on C. tamariscifolia could be in part explained because of its position in the littoral zone. On the other hand, the mechanical activity of sand grains among the fronds, mainly in winter, results in a lower abundance of epiphytes in C. humilis var. myriophylloides (Otero-Schmitt \& Pérez-Cirera, 1996). The presence of epiphytes in C. tamariscifolia is more or less regular, with a higher abundance in spring and summer, except in C. humilis var. myriophylloides. By contrast, C. baccata and C. usneoides presented the lowest variations, probably because of their optimal development in the subtidal, with a maximum in summer and a minimum at the end of autumn (Morales-Ayala \& Viera-Rodríguez, 1989; Otero-Schmitt, 1993; Otero-Schmitt \& Pérez-Cirera, 1996).

\section{THE NORTH ATLANTIC IBERIAN CYSTOSEIRA ASSEMBLAGES}

To study the diversity of the North Atlantic Iberian Cystoseira assemblages (C. baccata, C. foeniculacea, C. bumilis var. myriophylloides, C. nodicaulis, and C. usneoides), we used information from the literature (Miranda, 1931; Anadón \& al., 1979; Gili \& al., 1979; Fernández \& Niell, 1981, 1982; Otero-Schmitt, 1993; Bárbara, 1994; Gorostiaga, 1995; Gorostiaga \& Díez, 1996; Otero-Schmitt \& Pérez-Cirera, 1996; 2002; Araújo \& al., 2005, 2006; Cremades \& al., 2006; Peña \& Bárbara, 2006; Díaz Tapia \& al.,2011,2013; Bárbara \& al., 2013; Peña \& al., 2014) and grey information from herbaria, reports, pictures, unpublished data, etc. In tables 3 and 4, we present the associate flora of the six Cystoseira assemblages summarizing the information by species, taxonomic group, morpho-funtional group, life form, canopy layers, as well as common species and non-native ones. The assemblage of $C$. baccata harbors the biggest number of species (215), followed by C. tamariscifolia (162) and C. usneoides (126), whereas the community with fewest species was the $C$. foeniculacea one (34), probably because of the scarcity of studies about this species and probably the small distribution area of it. The numbers of epiphytes, non-native species and common ones follow a similar pattern between the Cystoseira communities. The most abundant division 
Table 3. Associate flora of Cystoseira assemblages in Northern Atlantic Iberian Peninsula (Miranda, 1931; Anadón \& al., 1979; Gili \& al., 1979; Fernández \& Niell, 1981, 1982; Otero-Schmitt, 1993; Bárbara, 1994; Gorostiaga, 1995; Gorostiaga \& Díez, 1996; Otero-Schmitt \& Pérez-Cirera, 1996; Araújo \& al., 2005, 2006; Cremades \& al., 2006; Peña \& Bárbara, 2006; Bárbara \& al., 2013; Díaz Tapia \& al., 2011, 2013; Peña \& al., 2014) and grey information (from herbaria, reports, pictures, unpublished data, etc.). For each species its position in the assemblage is mentioned: c = canopy/substrata, $\mathbf{e}=$ epiphyte. The canopies were divided in three layers based in Hardy-Halos \& al. (1973): $1=$ basal layer (<0.10 m, microbiotic and chamaebiotic strata); $\mathbf{2}=$ medium layer $(0.10-0.50 \mathrm{~m}$, meiobiotic strata); and $\mathbf{3}=$ upper layer $(0.50-5 \mathrm{~m}$, megabiotic and macrobiotic strata). The nine morphofunctional groups ( $\mathbf{1}=$ unicellular; $\mathbf{2}=$ thin foliose; $\mathbf{3}=$ intermediated foliose; $\mathbf{4}=$ corticated foliose; $\mathbf{5}=$ filamentous; $\mathbf{6}=$ filiform; $\mathbf{7}$ = corticated filiform; $\mathbf{8}$ = articulated calcareous; $\mathbf{9}=$ crustose) have been modified from Littler \& Littler (1984) and Steneck \& Dethier (1994). The five life forms ( $\mathbf{E}=$ Ephemerophytes; $\mathbf{H}=$ Hypnophytes; $\mathbf{P}=$ Phanerophytes; $\mathbf{C}=$ Chamaephytes; $\mathbf{H p}=$ Hemiphanerophytes $)$ were taken from Garbary (1976) and Fritsch (1981), based on Feldmann (1937).

\begin{tabular}{|c|c|c|c|c|c|c|c|c|c|c|c|c|}
\hline & $\frac{c}{\stackrel{0}{0}}$ & $\frac{\text { 응 }}{\stackrel{0}{0}}$ & 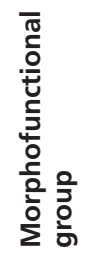 & 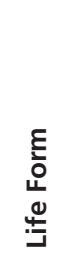 & 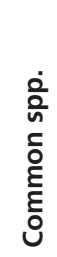 & $\begin{array}{l}\stackrel{0}{2} \\
\stackrel{1}{0} \\
\sum_{1} \\
\vdots \\
0 \\
2\end{array}$ & 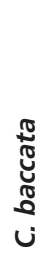 & 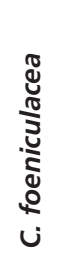 & 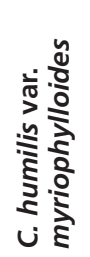 & 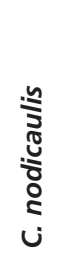 & 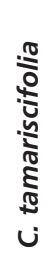 & 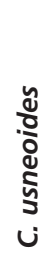 \\
\hline \multicolumn{13}{|l|}{ CYANOPHYTA } \\
\hline $\begin{array}{l}\text { Dermocarpella prasina (Reinsch) Komárek } \\
\& \text { anagnostidis }\end{array}$ & e & & 1 & $\mathrm{E}$ & & A & + & & & & + & + \\
\hline Oscillatoria tenuis C. Agardh ex Gomont & e & & 1 & $\mathrm{E}$ & & A & & & + & & & \\
\hline $\begin{array}{l}\text { Phormidium baculum (Gomont ex } \\
\text { Gomont) Anagnostidis }\end{array}$ & e & & 1 & $\mathrm{E}$ & & A & & & & & & + \\
\hline Bifurcaria bifurcata R. Ross & c & 2 & 7 & $P$ & & A & + & & + & & + & \\
\hline Carpomitra costata (Stackhouse) Batters & c & 2 & 7 & $\mathrm{P}$ & & A & & & & + & & \\
\hline $\begin{array}{l}\text { Cladostephus spongiosus (Hudson) } \\
\text { C. Agardh }\end{array}$ & c & 2 & 7 & $P$ & & A & + & & + & & + & \\
\hline Colpomenia peregrina Sauvageau & $\mathrm{c} / \mathrm{e}$ & 1 & 3 & $\mathrm{E}$ & + & I & + & & + & + & + & + \\
\hline $\begin{array}{l}\text { Colpomenia sinuosa (Mertens ex Roth) } \\
\text { Derbès \& Solier }\end{array}$ & $\mathrm{cle}$ & 1 & 3 & $\mathrm{E}$ & & A & & & & & + & \\
\hline $\begin{array}{l}\text { Cutleria adspersa (Mertens ex Roth) De } \\
\text { Notaris }\end{array}$ & cle & 1 & 3 & $\mathrm{H}$ & & A & & & & & + & \\
\hline Cutleria multifida (Turner) Greville & c/e & 2 & 3 & $\mathrm{H}$ & & A & + & & & & + & + \\
\hline $\begin{array}{l}\text { Cystoseira tamariscifolia (Hudson) } \\
\text { Papenfuss }\end{array}$ & c & 3 & 7 & $\mathrm{Hp}$ & & A & + & + & + & + & + & \\
\hline Cystoseira usneoides (L.) M. Roberts & c & 3 & 7 & $\mathrm{Hp}$ & & A & + & & & & & + \\
\hline Desmarestia aculeata (L.) J.V. Lamouroux & c & 3 & 7 & $\mathrm{P}$ & + & A & + & & & & + & + \\
\hline $\begin{array}{l}\text { Desmarestia ligulata (Stackhouse) } \\
\text { J.V. Lamouroux }\end{array}$ & c & 3 & 3 & $P$ & + & A & + & + & + & & + & + \\
\hline $\begin{array}{l}\text { Dictyopteris polypodioides (A.P. DC.) } \\
\text { J.V. Lamouroux }\end{array}$ & $\mathrm{cle}$ & 2 & 3 & $P$ & + & $A$ & + & + & + & + & + & \\
\hline $\begin{array}{l}\text { Dictyota dichotoma (Hudson) J.V. } \\
\text { Lamouroux }\end{array}$ & $\mathrm{cle}$ & 2 & 3 & $E$ & + & $A$ & + & + & + & + & + & + \\
\hline $\begin{array}{l}\text { Dictyota dichotoma var. intricata } \\
\text { (C. Agardh) Greville }\end{array}$ & C & 2 & 3 & $E$ & & $A$ & + & & & & + & + \\
\hline
\end{tabular}


Table 3. (Continued)

\begin{tabular}{|c|c|c|c|c|c|c|c|c|c|c|c|c|}
\hline & $\begin{array}{l}\frac{5}{0} \\
\frac{+}{n} \\
0 \\
0\end{array}$ & $\begin{array}{l}\frac{2}{0} \\
\frac{0}{0} \\
\text { ত }\end{array}$ & 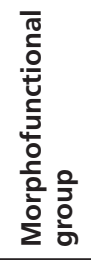 & 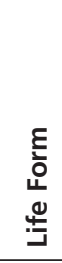 & 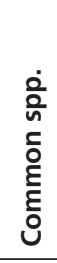 & $\begin{array}{l}\stackrel{0}{\geq} \\
\underset{\pi}{\pi} \\
\frac{1}{1} \\
\frac{1}{2} \\
z\end{array}$ & 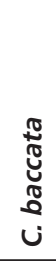 & 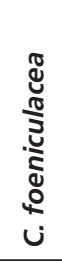 & 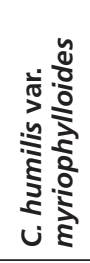 & 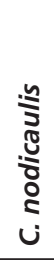 & 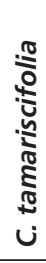 & 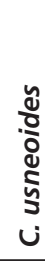 \\
\hline Ectocarpus fasciculatus Harvey & e & & 5 & $\mathrm{E}$ & & A & + & & & & + & + \\
\hline Ectocarpus siliculosus (Dillwyn) Lyngbye & $\mathrm{cle}$ & 1 & 5 & $\mathrm{E}$ & & A & + & & & & + & + \\
\hline Elachista flaccida (Dillwyn) Fries & e & & 5 & $\mathrm{E}$ & + & A & + & & & & + & + \\
\hline $\begin{array}{l}\text { Elachista intermedia P.L. Crouan \& } \\
\text { H.M. Crouan }\end{array}$ & e & & 5 & $\mathrm{E}$ & & A & + & & & & & \\
\hline $\begin{array}{l}\text { Feldmannia lebelii (Areschoug ex P.L. } \\
\text { Crouan \& H.M. Crouan) G. Hamel }\end{array}$ & e & & 5 & $\mathrm{E}$ & & A & & & & & + & \\
\hline Feldmannia mitchelliae (Harvey) H.S. Kim & $\mathrm{cle}$ & 1 & 5 & $\mathrm{E}$ & & A & + & & & & + & \\
\hline $\begin{array}{l}\text { Feldmannia simplex (P.L. Crouan \& H.M. } \\
\text { Crouan) G. Hamel }\end{array}$ & e & & 5 & $\mathrm{E}$ & & A & & & & & + & \\
\hline Fucus serratus L. & c & & 4 & $P$ & & A & + & & & + & & + \\
\hline Halidrys siliquosa (L.) Lyngbye & c & 3 & 7 & $P$ & + & A & + & & + & + & & + \\
\hline Halopteris filicina (Grateloup) Kützing & $\mathrm{cle}$ & 1 & 6 & $P$ & + & A & + & & + & + & & \\
\hline Halopteris scoparia (L.) Sauvageau & $\mathrm{c} / \mathrm{e}$ & 2 & 7 & $P$ & + & A & + & & + & & + & + \\
\hline $\begin{array}{l}\text { Herponema valiantei (Bornet ex } \\
\text { Sauvageau) G. Hamel }\end{array}$ & e & & 5 & $\mathrm{H}$ & & A & & & & & + & \\
\hline Himanthalia elongata (L.) S.F. Gray & c & 3 & 4 & $P$ & & A & + & & & & + & \\
\hline Hincksia granulosa (Smith) P.C. Silva & $\mathrm{cle}$ & 1 & 5 & $\mathrm{E}$ & + & A & + & & & & + & + \\
\hline Hincksia hincksiae (Harvey) P.C. Silva & e & & 5 & $\mathrm{E}$ & + & A & + & & & & + & + \\
\hline Hincksia sandriana (Zanardini) P.C. Silva & $\mathrm{cle}$ & 1 & 5 & $\mathrm{H}$ & & A & + & & & & + & + \\
\hline Hincksia secunda (Kützing) P.C. Silva & e & & 5 & $\mathrm{E}$ & & A & + & & & & + & + \\
\hline Kuckuckia spinosa (Kützing) Kornmann & $\mathrm{e}$ & & 5 & $\mathrm{E}$ & & A & + & & & & & \\
\hline Laminaria hyperborea (Gunnerus) Foslie & cle & 3 & 4 & $\mathrm{Hp}$ & + & A & + & & + & & + & + \\
\hline Laminaria ochroleuca Bachelot de la Pylaie & c & 3 & 4 & $P$ & + & A & + & & & + & + & + \\
\hline Leathesia marina (Lyngbye) Decaisne & c & 1 & 3 & $\mathrm{E}$ & & A & & & & & + & \\
\hline Litosiphon laminariae (Lyngbye) Harvey & e & & 6 & $\mathrm{H}$ & & A & + & & & & & \\
\hline $\begin{array}{l}\text { Myriactula rivulariae (Suhr ex Areschoug) } \\
\text { Feldmann }\end{array}$ & e & & 5 & $\mathrm{E}$ & & A & & + & & & + & \\
\hline Myrionema strangulans Greville & e & & 2 & $\mathrm{E}$ & & A & + & & & & & + \\
\hline Petalonia fascia (O.F. Müller) Kuntze & $\mathrm{cle}$ & 1 & 3 & $\mathrm{H}$ & & A & + & & & & + & \\
\hline $\begin{array}{l}\text { Phyllariopsis brevipes subsp. } \\
\text { pseudopurpurascens Pérez-Cirera \& al. }\end{array}$ & cle & 2 & 4 & $\mathrm{H}$ & & A & + & & & & & + \\
\hline $\begin{array}{l}\text { Phyllariopsis purpurascens (C. Agardh) } \\
\text { E.C. Henry \& G.R. South }\end{array}$ & c & 2 & 4 & $\mathrm{H}$ & & A & + & & & & & \\
\hline Ralfsia verrucosa (Areschoug) Areschoug & e & & 9 & $\mathrm{C}$ & & A & + & & & & & \\
\hline $\begin{array}{l}\text { Saccharina latissima (L.) C.E. Lane, } \\
\text { C. Mayes, Druehl \& G.W. Saunders }\end{array}$ & cle & 3 & 4 & $P$ & & A & + & & & & + & + \\
\hline $\begin{array}{l}\text { Saccorhiza polyschides (Lightfoot) } \\
\text { Batters }\end{array}$ & cle & 3 & 4 & $\mathrm{H}$ & + & A & + & & + & & + & + \\
\hline Sargassum muticum (Yendo) Fensholt & C & 3 & 7 & $\mathrm{Hp}$ & + & I & + & & + & & + & + \\
\hline Sphacelaria cirrosa (Roth) C. Agardh & cle & 1 & 6 & $\mathrm{E}$ & + & A & + & & + & & + & + \\
\hline Sphacelaria rigidula Kützing & e & & 6 & $\mathrm{E}$ & & A & + & & & & + & \\
\hline
\end{tabular}


Table 3. (Continued)

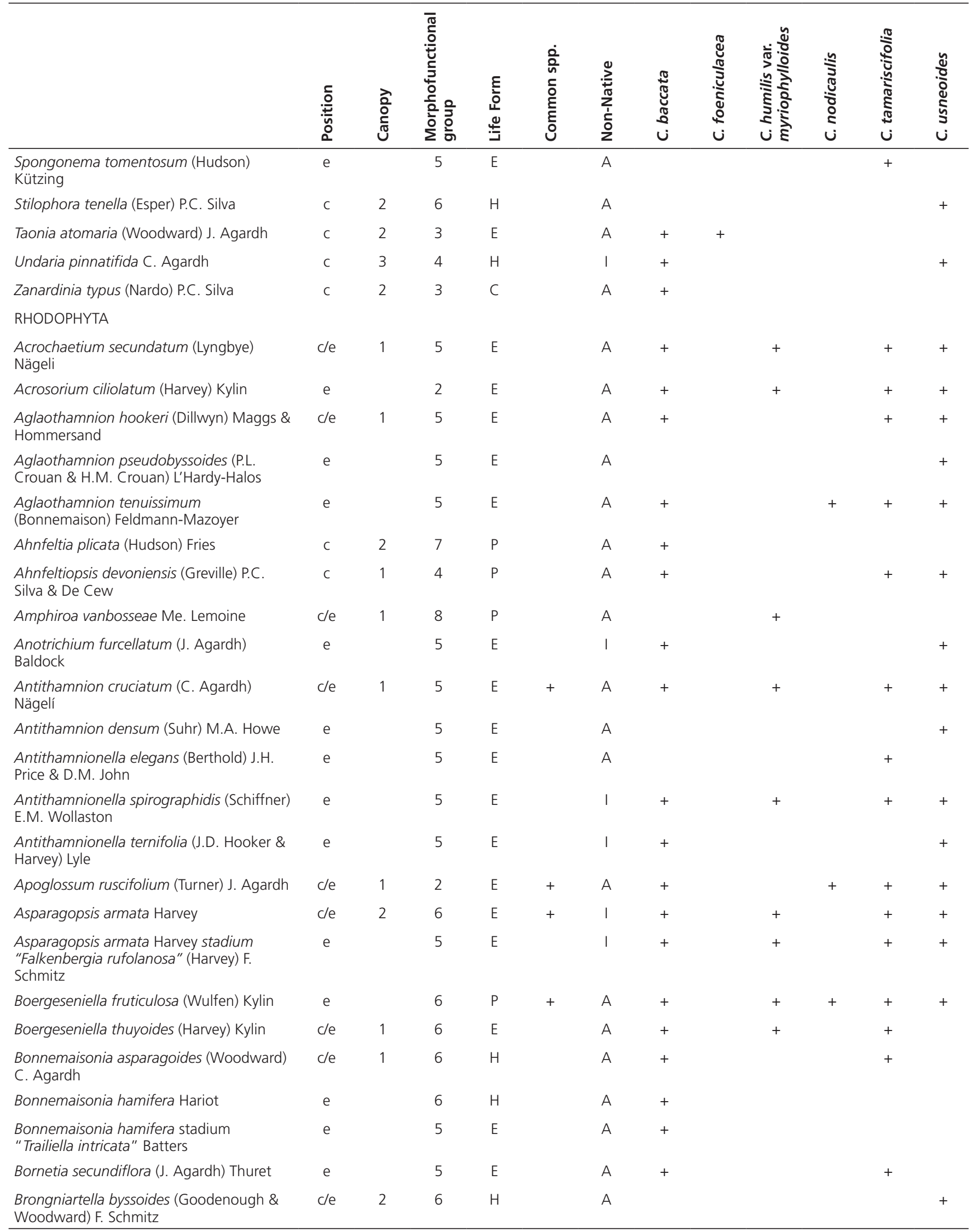


Table 3. (Continued)

\begin{tabular}{|c|c|c|c|c|c|c|c|c|c|c|c|c|}
\hline & $\begin{array}{l}\frac{0}{0} \\
\frac{1}{n} \\
0 \\
0\end{array}$ & $\begin{array}{l}\text { 긍 } \\
\frac{0}{0} \\
\frac{0}{0}\end{array}$ & 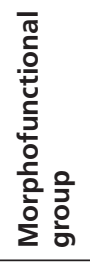 & 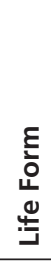 & 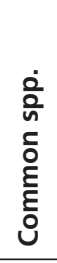 & 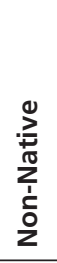 & 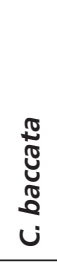 & 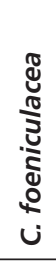 & 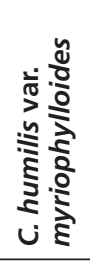 & 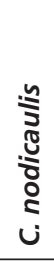 & 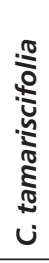 & 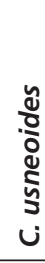 \\
\hline Calliblepharis ciliata (Hudson) Kützing & $\mathrm{cle}$ & 2 & 4 & $P$ & & A & + & & & & & + \\
\hline $\begin{array}{l}\text { Callithamnion corymbosum (Smith) } \\
\text { Lyngbye }\end{array}$ & $\mathrm{c} / \mathrm{e}$ & 1 & 5 & $\mathrm{E}$ & & A & + & & & & + & \\
\hline $\begin{array}{l}\text { Callithamnion granulatum (Ducluzeau) C. } \\
\text { Agardh }\end{array}$ & cle & 1 & 5 & $\mathrm{E}$ & & A & + & & & & + & + \\
\hline $\begin{array}{l}\text { Callithamnion tetragonum (Withering) S.F. } \\
\text { Gray }\end{array}$ & e & & 5 & $\mathrm{E}$ & + & A & + & & + & & + & + \\
\hline Callophyllis laciniata (Hudson) Kützing & $\mathrm{c} / \mathrm{e}$ & 2 & 4 & $P$ & + & A & + & & & + & + & + \\
\hline $\begin{array}{l}\text { Ceramium botryocarpum A.W. Griffiths ex } \\
\text { Harvey }\end{array}$ & e & & 6 & $\mathrm{H}$ & & A & & & & & + & \\
\hline Ceramium ciliatum (J. Ellis) Ducluzeau & $\mathrm{c} / \mathrm{e}$ & 1 & 6 & $\mathrm{H}$ & + & A & + & & + & & + & + \\
\hline Ceramium diaphanum (Lightfoot) Roth & $\mathrm{e}$ & & 5 & $\mathrm{H}$ & + & A & + & & + & + & + & + \\
\hline Ceramium echionotum J. Agardh & e & & 5 & $\mathrm{H}$ & & A & + & & & & + & \\
\hline $\begin{array}{l}\text { Ceramium gaditanum (Clemente) } \\
\text { Cremades }\end{array}$ & c & 1 & 6 & $\mathrm{E}$ & & A & + & & & & + & \\
\hline $\begin{array}{l}\text { Ceramium pallidum (Nägeli ex Kützing) } \\
\text { Maggs \& Hommersand }\end{array}$ & e & & 6 & $\mathrm{E}$ & & A & + & & & & + & \\
\hline $\begin{array}{l}\text { Chondracanthus acicularis (Roth) } \\
\text { Frederica }\end{array}$ & $\mathrm{cle}$ & 1 & 7 & $P$ & + & A & + & & + & & + & + \\
\hline $\begin{array}{l}\text { Chondracanthus teedei (Mertens ex Roth) } \\
\text { Kützing }\end{array}$ & $\mathrm{cle}$ & 2 & 7 & $P$ & + & A & + & & + & + & + & + \\
\hline $\begin{array}{l}\text { Chondria coerulescens (J. Agardh) } \\
\text { Falkenberg }\end{array}$ & c & 1 & 6 & $\mathrm{E}$ & & A & + & & & & + & \\
\hline $\begin{array}{l}\text { Chondria dasyphylla (Woodward) } \\
\text { C. Agardh }\end{array}$ & c & 2 & 6 & $\mathrm{E}$ & & A & + & & & & & \\
\hline Chondria scintillans Feldmann-Mazoyer & c & 2 & 6 & $P$ & & A & + & & & & & \\
\hline Chondrus crispus Stackhouse & c & 2 & 4 & $P$ & + & A & + & + & + & + & + & + \\
\hline Chylocladia verticillata (Lightfoot) Bliding & e & & 6 & $\mathrm{E}$ & + & A & + & & & + & + & + \\
\hline Colaconema daviesii (Dillwyn) Stegenga & e & & 5 & $\mathrm{E}$ & + & A & + & & + & & + & + \\
\hline $\begin{array}{l}\text { Colaconema endophyticum (Batters) } \\
\text { J.T. Harper \& G.W. Saunders }\end{array}$ & e & & 2 & $\mathrm{E}$ & & A & & & & & + & \\
\hline $\begin{array}{l}\text { Colaconema infestans (M.A. Howe \& Hoyt) } \\
\text { Woelkerling }\end{array}$ & e & & 2 & $\mathrm{E}$ & & A & & & & & & + \\
\hline Compsothamnion thuyoides (Smith) Nägeli & e & & 5 & $E$ & & A & + & & & & & \\
\hline Corallina officinalis L. & c & 1 & 8 & $P$ & + & A & + & + & & + & + & \\
\hline
\end{tabular}


Table 3. (Continued)

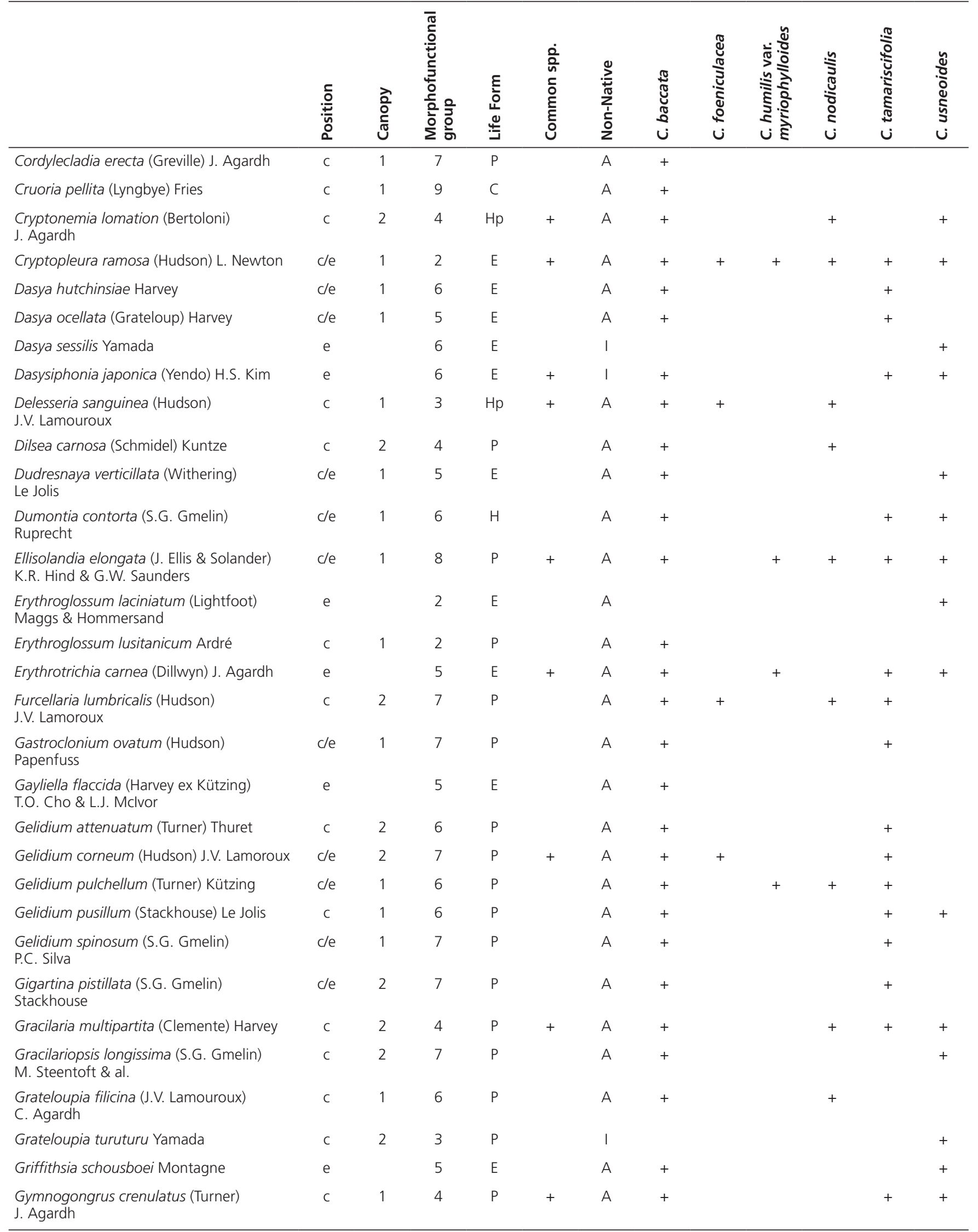


Table 3. (Continued)

\begin{tabular}{|c|c|c|c|c|c|c|c|c|c|c|c|c|}
\hline & $\begin{array}{l}\frac{0}{0} \\
\frac{.}{n} \\
0\end{array}$ & $\begin{array}{l}\frac{\lambda}{0} \\
\frac{0}{0} \\
\text { U. }\end{array}$ & 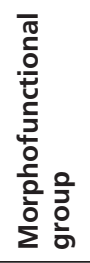 & 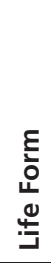 & 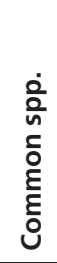 & 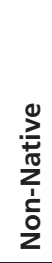 & 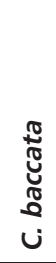 & 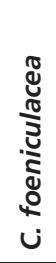 & 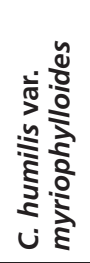 & 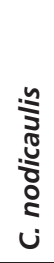 & 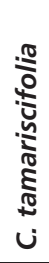 & 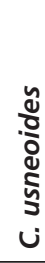 \\
\hline $\begin{array}{l}\text { Gymnogongrus griffithsiae (Turner) } \\
\text { Martius }\end{array}$ & c & 1 & 7 & $\mathrm{P}$ & & A & + & & & & & \\
\hline $\begin{array}{l}\text { Halarachnion ligulatum (Woodward) } \\
\text { Kützing }\end{array}$ & c & 2 & 3 & $\mathrm{H}$ & & A & + & & & & & + \\
\hline Halopithys incurva (Hudson) Batters & c & 2 & 7 & $P$ & & A & + & & & & & \\
\hline Halurus equisetifolius (Lightfoot) Kützing & $\mathrm{c} / \mathrm{e}$ & 1 & 6 & $\mathrm{E}$ & & A & + & + & & & + & \\
\hline $\begin{array}{l}\text { Halymenia latifolia P.L. Crouan \& H.M. } \\
\text { Crouan ex Kützing }\end{array}$ & c & 2 & 3 & $\mathrm{H}$ & & A & + & & & & & + \\
\hline $\begin{array}{l}\text { Haraldiophyllum bonnemaisonii (Kylin) } \\
\text { A.D. Zinova }\end{array}$ & e & & 2 & $\mathrm{E}$ & & A & + & & & & & + \\
\hline $\begin{array}{l}\text { Herposiphonia tenella (C. Agardh) } \\
\text { Ambronn }\end{array}$ & e & & 5 & $\mathrm{H}$ & & A & & & & & + & + \\
\hline Heterosiphonia plumosa (J. Ellis) Batters & $\mathrm{c} / \mathrm{e}$ & 2 & 5 & $P$ & + & A & + & + & + & + & + & + \\
\hline $\begin{array}{l}\text { Hildenbrandia rubra (Sommerfelt) } \\
\text { Meneghini }\end{array}$ & c & 1 & 9 & C & & A & + & & & & & \\
\hline $\begin{array}{l}\text { Hypoglossum hypoglossoides (Stackhouse) } \\
\text { F.S. Collins \& hervey }\end{array}$ & $\mathrm{cle}$ & 1 & 2 & $\mathrm{E}$ & & A & + & & & & + & + \\
\hline Jania longifurca Zanardini & $\mathrm{cle}$ & 1 & 8 & $P$ & & A & + & & & & + & \\
\hline Jania rubens (L.) J.V. Lamouroux & e & & 8 & $P$ & + & A & + & + & + & + & + & + \\
\hline Jania squamata (L.) J.H. Kim \& al. & e & & 8 & $P$ & + & A & + & + & & & + & \\
\hline Kallymenia reniformis (Turner) J. Agardh & c/e & 2 & 4 & $P$ & + & A & + & + & & & & + \\
\hline $\begin{array}{l}\text { Laurencia pyramidalis Bory de Saint- } \\
\text { Vincent ex Kützing }\end{array}$ & $\mathrm{c} / \mathrm{e}$ & 1 & 7 & $\mathrm{H}$ & & A & + & & & & & \\
\hline Leptosiphonia schousboei (Thuret) Kylin & $\mathrm{c} / \mathrm{e}$ & 1 & 6 & $\mathrm{H}$ & & A & & & + & & + & \\
\hline Lithophyllum incrustans Philippi & c & 1 & 9 & C & + & A & + & + & + & + & + & + \\
\hline Lomentaria articulata (Hudson) Lyngbye & cle & 1 & 6 & $P$ & + & A & + & + & + & + & + & + \\
\hline $\begin{array}{l}\text { Lomentaria clavellosa (Lightfoot ex Turner) } \\
\text { Gaillon }\end{array}$ & $\mathrm{c} / \mathrm{e}$ & 1 & 6 & $\mathrm{E}$ & & A & + & & & & + & + \\
\hline Lomentaria hakodatensis Yendo & c & 1 & 6 & $P$ & & I & & & & & + & \\
\hline Lophosiphonia reptabunda (Suhr) Kylin & e & & 5 & $\mathrm{E}$ & & A & & & & & + & \\
\hline Mastocarpus stellatus (Stackhouse) Guiry & c & 1 & 4 & $P$ & & A & + & & & & + & + \\
\hline $\begin{array}{l}\text { Mastocarpus stellatus stadium "Petrocelis } \\
\text { cruenta" J. Agardh }\end{array}$ & c & 1 & 9 & C & & A & + & & & & + & + \\
\hline $\begin{array}{l}\text { Melobesia membranacea (Esper) } \\
\text { J.V. Lamouroux }\end{array}$ & e & & 9 & C & + & A & + & & & & + & + \\
\hline $\begin{array}{l}\text { Meredithia microphylla (J. Agardh) } \\
\text { J. Agardh }\end{array}$ & c & 1 & 4 & $\mathrm{P}$ & & A & + & & & & & \\
\hline $\begin{array}{l}\text { Mesophyllum lichenoides (J. Ellis) } \\
\text { M. Lemoine }\end{array}$ & $\mathrm{c} / \mathrm{e}$ & 1 & 9 & C & + & A & + & & + & + & + & \\
\hline Monosporus pedicellatus (Smith) Solier & e & & 5 & $\mathrm{E}$ & & A & & & & & & + \\
\hline $\begin{array}{l}\text { Neosiphonia collabens (C. Agardh) Díaz- } \\
\text { Tapia \& Bárbara }\end{array}$ & e & & 6 & $\mathrm{E}$ & & A & + & & & & + & + \\
\hline $\begin{array}{l}\text { Neosiphonia ferulacea (Suhr ex J. Agardh) } \\
\text { S.M. Guimaraes \& M.T. Fujii }\end{array}$ & e & & 6 & $\mathrm{E}$ & & A & + & & & & + & + \\
\hline $\begin{array}{l}\text { Neosiphonia harveyi (Bailey) } \\
\text { M.S. Kim \& al. }\end{array}$ & e & & 6 & $\mathrm{E}$ & & 1 & + & & & & & \\
\hline
\end{tabular}


Table 3. (Continued)

\begin{tabular}{|c|c|c|c|c|c|c|c|c|c|c|c|c|}
\hline & $\frac{c}{\frac{c}{0}}$ & 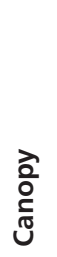 & 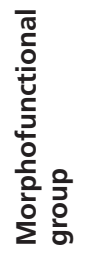 & 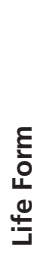 & 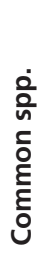 & $\begin{array}{l}\sum_{0}^{0} \\
\sum_{0} \\
\sum_{1} \\
0 \\
z\end{array}$ & 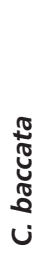 & 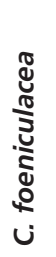 & 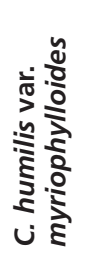 & 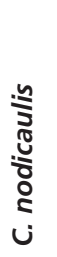 & 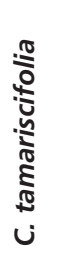 & 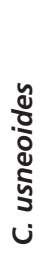 \\
\hline $\begin{array}{l}\text { Nitophyllum punctatum (Stackhouse) } \\
\text { Greville }\end{array}$ & c/e & 1 & 2 & E & + & A & + & & + & + & + & + \\
\hline $\begin{array}{l}\text { Osmundea hybrida (A.P. de Candolle) } \\
\text { K.W. Nam }\end{array}$ & c & 1 & 7 & $\mathrm{H}$ & & A & & & & & + & \\
\hline $\begin{array}{l}\text { Osmundea osmunda (S.G. Gmelin) } \\
\text { K.W. Nam \& Maggs }\end{array}$ & c & 2 & 7 & $P$ & & A & + & & & & + & \\
\hline Palmaria palmata (L.) Wber \& Mohr & c/e & 2 & 4 & $P$ & & A & + & + & & & + & \\
\hline $\begin{array}{l}\text { Peyssonnelia atropurpurea P.L. Crouan \& } \\
\text { H.M. Crouan }\end{array}$ & c & 1 & 9 & $\mathrm{C}$ & + & A & + & & & + & + & + \\
\hline $\begin{array}{l}\text { Peyssonnelia dubyi P.L. Crouan \& H.M. } \\
\text { Crouan }\end{array}$ & c & 1 & 9 & C & & A & + & & & & & + \\
\hline $\begin{array}{l}\text { Peyssonnelia squamaria (S.G. Gmelin) } \\
\text { Decaisne }\end{array}$ & c & 1 & 9 & C & & A & + & & & & & \\
\hline Phyllophora crispa (Hudson) P.S. Dixon & c & 1 & 4 & $P$ & & A & + & & & & & \\
\hline $\begin{array}{l}\text { Phyllophora sicula (Kützing) Guiry \& L.M. } \\
\text { Irvine }\end{array}$ & c & 1 & 3 & $P$ & & A & + & & & & & \\
\hline $\begin{array}{l}\text { Polyneura bonnemaisonii (C. Agardh) } \\
\text { Maggs \& Hommersand }\end{array}$ & c/e & 1 & 2 & E & & A & + & & & + & & + \\
\hline $\begin{array}{l}\text { Polysiphonia atlantica Kapraun \& } \\
\text { J.N. Norris }\end{array}$ & cle & 1 & 5 & $\mathrm{E}$ & & A & + & & & & & \\
\hline Polysiphonia brodiaei (Dillwyn) Sprengel & $\mathrm{c} / \mathrm{e}$ & 1 & 6 & $E$ & & A & + & & + & & + & + \\
\hline $\begin{array}{l}\text { Polysiphonia caespitosa (M.A. Pocock) } \\
\text { Hollenberg }\end{array}$ & c & 1 & 5 & $\mathrm{E}$ & & A & + & & & & + & \\
\hline $\begin{array}{l}\text { Polysiphonia denudata (Dillwyn) Greville } \\
\text { ex Harvey }\end{array}$ & e & & 6 & E & & A & + & & & & & \\
\hline Polysiphonia elongata (Hudson) Sprengel & c/e & 1 & 6 & $\mathrm{E}$ & & A & & & & & + & \\
\hline Polysiphonia fibrillosa (Dillwyn) Sprengel & $\mathrm{e}$ & & 5 & E & & A & + & & & & + & + \\
\hline Polysiphonia fucoides (Hudson) Greville & c & 1 & 6 & $P$ & & A & + & & & & & \\
\hline Polysiphonia stricta (Dillwyn) Greville & e & & 5 & E & & A & & & & + & & \\
\hline Polysiphonia subulata (Ducluzeau) Kützing & $\mathrm{e}$ & & 5 & E & & A & & & & & + & \\
\hline Porphyra umbilicalis Kützing & c/e & 1 & 2 & $E$ & & A & + & & & & + & + \\
\hline $\begin{array}{l}\text { Porphyrostromium boryanum (Montagne) } \\
\text { P.C. Silva }\end{array}$ & e & & 2 & $\mathrm{E}$ & & A & + & & & & + & \\
\hline $\begin{array}{l}\text { Pseudopolyides furcellarioides } \\
\text { Gallardo \& al. }\end{array}$ & c & 2 & 7 & $P$ & + & A & + & + & & + & + & \\
\hline
\end{tabular}


Table 3. (Continued)

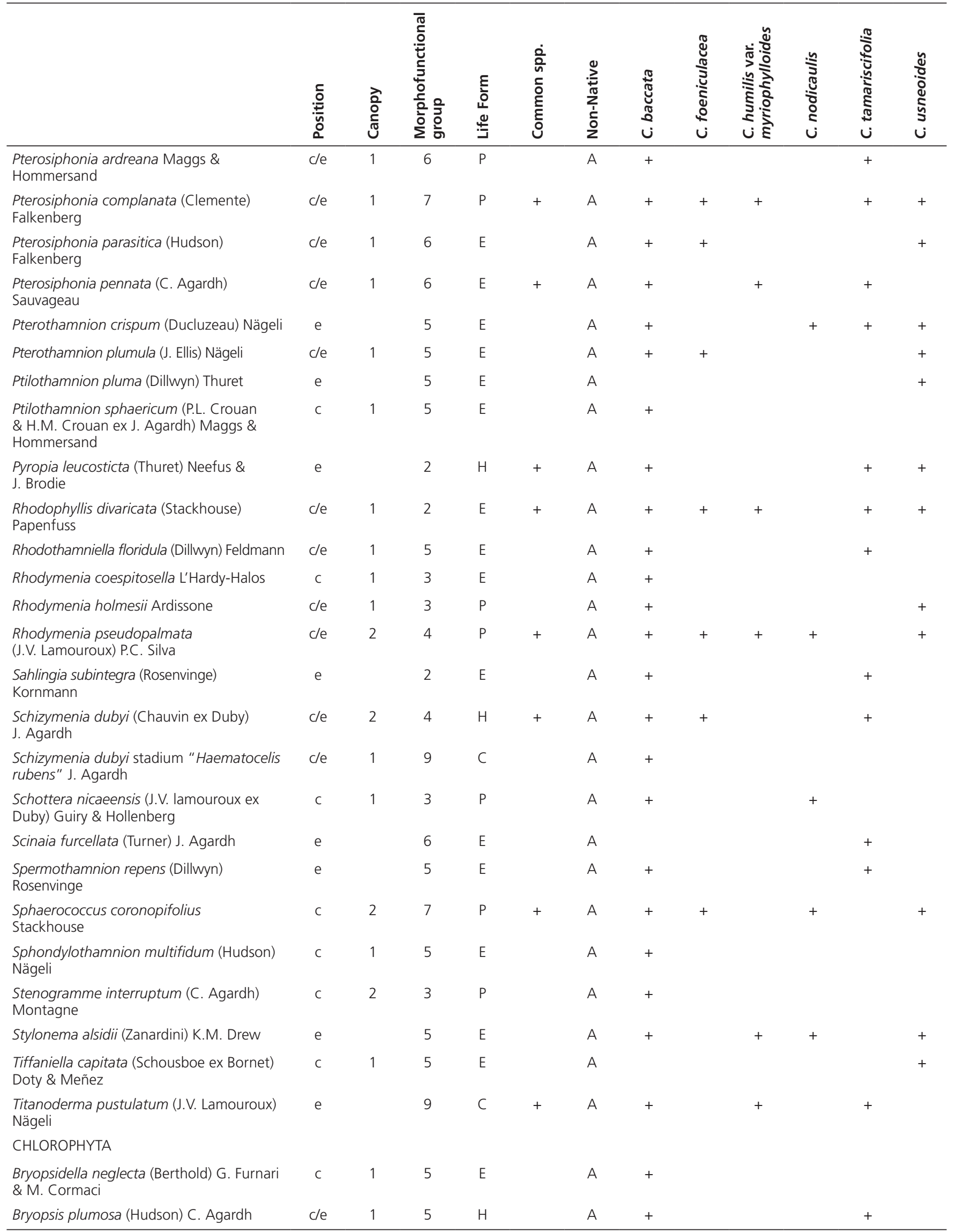


Table 3. (Continued)

\begin{tabular}{|c|c|c|c|c|c|c|c|c|c|c|c|c|}
\hline & 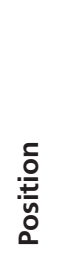 & $\frac{\text { }}{\frac{0}{0}}$ & 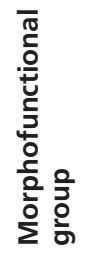 & 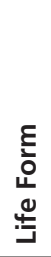 & 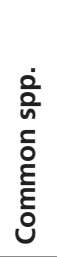 & $\begin{array}{l}\sum_{0}^{0} \\
\sum_{0} \\
\vdots \\
0 \\
2\end{array}$ & 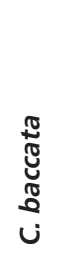 & 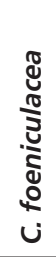 & 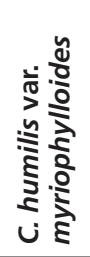 & 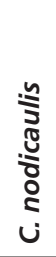 & 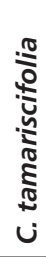 & 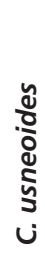 \\
\hline Chaetomorpha aerea (Dilwyn) Kützing & c/e & 1 & 5 & $\mathrm{E}$ & + & A & + & & + & & + & \\
\hline Cladophora albida (Nees) Kützing & $\mathrm{c} / \mathrm{e}$ & 1 & 5 & $\mathrm{E}$ & & A & + & & & & + & + \\
\hline $\begin{array}{l}\text { Cladophora hutchinsiae (Dillwyn) } \\
\text { Kützing }\end{array}$ & c/e & 1 & 5 & $\mathrm{E}$ & & A & & & & & + & + \\
\hline $\begin{array}{l}\text { Cladophora laetevirens (Dillwyn) } \\
\text { Kützing }\end{array}$ & cle & 1 & 5 & $\mathrm{E}$ & & A & + & & & & + & \\
\hline Cladophora rupestris (L.) Kützing & c & 1 & 5 & $\mathrm{E}$ & & A & + & & & & & \\
\hline Codium fragile (Suringar) Hariot & c & 2 & 6 & $P$ & & A & + & & & & + & + \\
\hline Codium tomentosum Stackhouse & c & 2 & 6 & $P$ & + & A & + & + & + & & + & \\
\hline Codium vermilara (Olivi) Delle Chiaje & c & 2 & 6 & $\mathrm{P}$ & & A & + & & & & & + \\
\hline Spongomorpha arcta (Dillwyn) Kützing & c & 1 & 5 & $\mathrm{H}$ & & A & & & & & + & \\
\hline Ulva ardreana M. Cormaci \& al. & e & & 2 & $E$ & & A & + & & & & & \\
\hline Ulva clathrata (Roth) C. Agardh & e & & 2 & $E$ & + & A & + & & + & & + & + \\
\hline Ulva compressa L. & c/e & 1 & 2 & $\mathrm{E}$ & & A & + & & & & + & + \\
\hline
\end{tabular}

in the Cystoseira communities was Rhodophyta (24-148 species), followed by Ochrophyta (9-46) and Chlorophyta (1-19). Cyanophyta (up to 3 species) is a not well studied group due to the difficulty to found and determinate them. This distribution of the species among the divisions is very similar to the number of algal species recorded on subtidal Atlantic maerl beds (Peña \& al., 2014), although it seems to be more similar to the France Atlantic region than to the Spain Atlantic region.

The predominant morphofunctional groups (Table 4) were those of filamentous and filiform, followed by the three foliose groups. Among morphological groups, the most abundant varies between the communities. Thus, in the $C$. baccata, C. tamariscifolia, and C. usneoides communities the filamentous morphological group which includes most species was the thin filamentous $(55,47$, and 37 species, respectively), while $C$. foeniculacea community was the corticated filiform (10). In contrast, in the C. bumilis var. myriophylloides and C. nodicaulis, the three filamentous morphological groups were very similar (7-13). On the other hand, the three foliose morphological groups (thin to corticated) were similar among the $C$. baccata, C. tamariscifolia, and C. usneoides assemblages. Concerning the life forms of the associate flora to C. baccata, C. tamariscifolia, and C. usneoides (Table 4), the predominant group was the ephemerophytes $(97,82$ and 69 species) and phanerophytes (71, 44 and 32 species). This means that Cystoseira assemblages exhibit a constant number of species throughout the year, both by perennial plants (phanerophytes) or constant renewing of individuals by nonperennial plants (ephemerophytes).

More than 70 species were present in the majority of the Cystoseira assemblages (Table 3), the most of them appearing in the $C$. baccata community. The erect canopy were made by brown algae like Desmarestia aculeata, Desmarestia ligulata, Halidrys siliquosa, Laminaria byperborea, Laminaria ochroleuca, Saccorbiza polyschides, Sargassum muticum living together to Cystoseira species. Other species (mainly red and brown seaweeds) formed a basal canopy, as Callopbyllis laciniata, Calliblepharis jubata, Codium tomentosum, Corallina officinalis, Chondrus crispus, Delesseria sanguinea, Dictyota dichotoma, Dictyopteris polypodioides, Ellisolandia elongata, Lithophyllum incrustans, Gelidium corneum, Heterosiphonia 
Table 4. Summary of the associate flora of Cystoseira assemblages in the Northern Atlantic Iberian Peninsula.

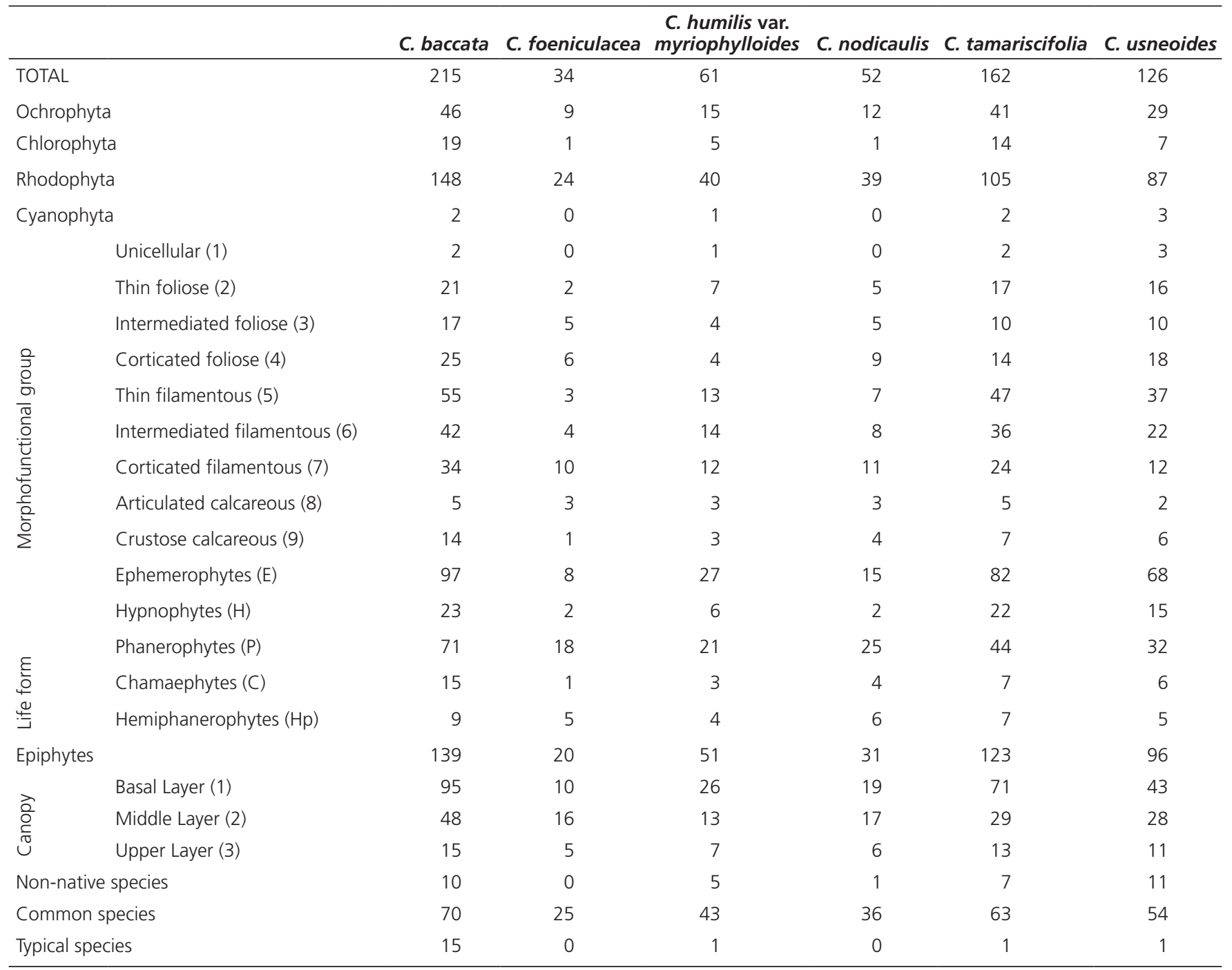

plumosa, Lomentaria articulata, Mesophyllum lichenoides, Plocamium cartilagineum, Pseudopolyides furcellarioides, Pterosiphonia complanata, Rhodymenia pseudopalmata, Sphaerococcus coronopifolius, and Ulva rigida. There were also some epiphytes common in the most of the Cystoseira assemblages, as Antithamnion cruciatum, Boergeseniella fruticulosa, Champia parvula, Colaconema daviesii, Colpomenia peregrina, Cryptopleura ramosa, Elachista flaccida, Rhodophyllis divaricata, Hincksia hincksiae, Jania rubens, J. squamata, Melobesia membranacea, Pyropia leucosticta, Titanoderma pustulatum, and Ulva clathrata (Tab. 3, Fig. 3). Other species found as typical epiphytes but not present in all the Cystoseira assemblages were brown seaweeds (Ectocarpus fasciculatus, Elachista intermedia, Hincksia granulosa, Litosiphon laminariae, and Myriactula rivularia spp.) and red algae (Callithamnion tetragonum, Chylocladia verticillata, Compsothamnion thuyoides, Mesophyllum lichenoides, Nitophyllum punctatum, Polyneura bonnemaisonii, Rhodophyllis divaricata, Schizymenia dubyi, and Spermothamnion repens).

The number of exclusive species by Cystoseira assemblages varies between communities. Neither species were exclusive of the C. foeniculacea and the C. nodicaulis communities, whereas the C. bumilis var. myriophylloides and the C. tamariscifolia communities exhibit Amphiroa vanbosseae and Jania longifurca as typical species, respectively. The C. usneoides community contained two species (Erythroglossum laciniatum and Brongniartella byssoides) not present in other Cystoseira assemblages. Cystoseira baccata community comprises great number of species (Table 3) that are absent or scarce in other Cystoseira assemblages, such as Phyllariopsis brevipes subsp. pseudopurpurascens, Abnfeltia plicata, Chondria dasyphylla, C. scintillans, Cordylecladia erecta, Cruoria pellita, Elachista flaccida, Erythroglossum lusitanicum, Halopithys incurva, Laurencia pyramidalis, Meredithia microphylla, Neurocaulon foliosum, Phyllophora crispa, P. sicula, Plocamium raphelisianum, and Polysiphonia fucoides.

Regarding the non-native algae in the Cystoseira communities (Tables 3 and 4), up to twelve species have been reported in the literature, as canopy over rocks (Codium fragile, Lomentaria hakodatensis, Sargassum muticum, and Undaria pinnatifida) and epiphytes Anotrichium furcellatum, Antithamnionella spirographidis, A. ternifolia, Asparagopsis armata, and its stadium "Falkenbergia rufolanosa", 

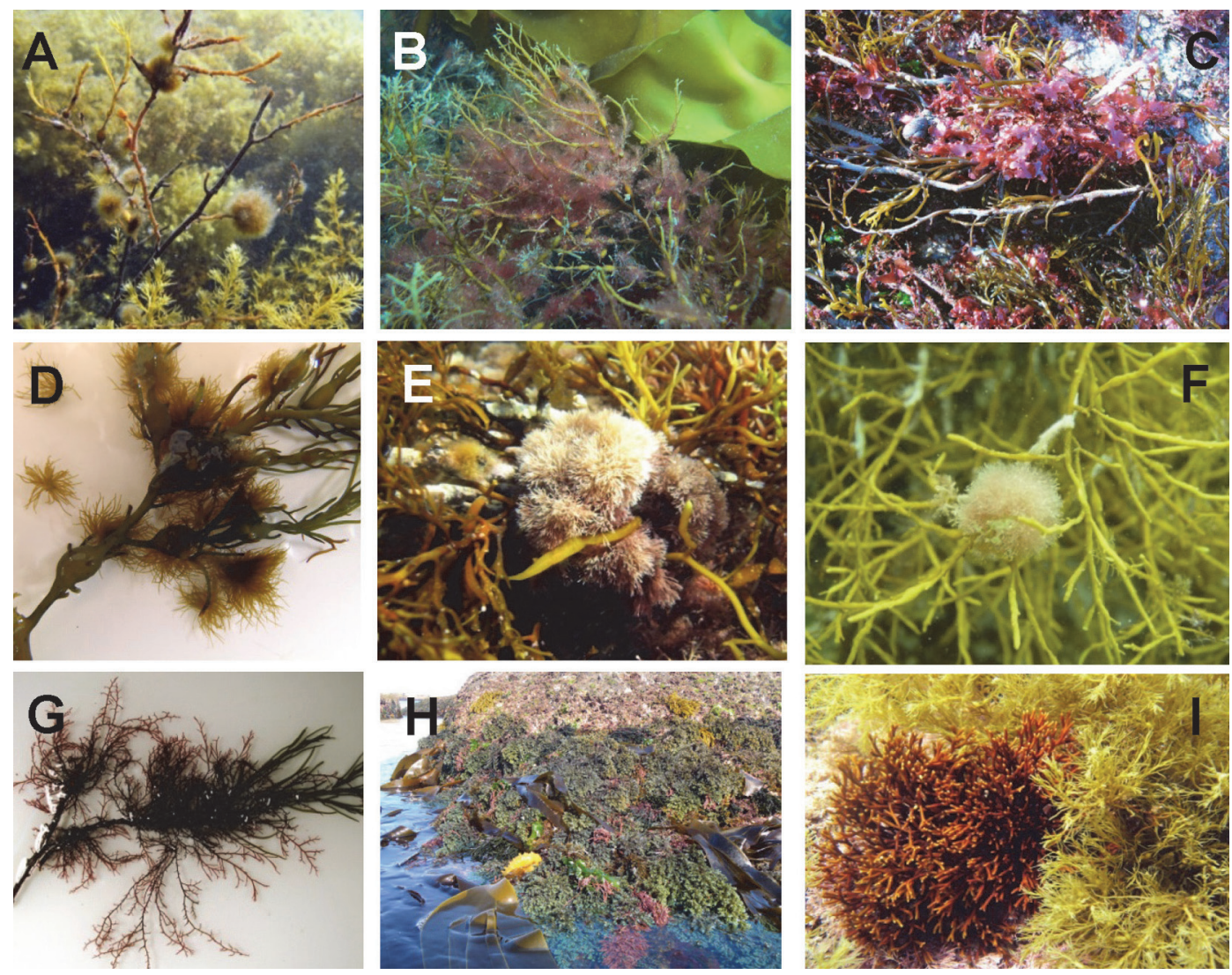

Fig. 3. Epiphytes and associate species of the Northern Atlantic Iberian Cystoseira assemblages: a, Sphacelaria cirhosa; b, Antithamnionella ternifolia, c, Cryptopleura ramosa; d, Elachista flaccida; e, Jania rubens; $\mathbf{f}$, Asparagopsis armata as tetrasporangial stadium (Falkenbergia rufolanosa); $\mathbf{g}$, Boergeseniella fruticulosa; h, C. tamariscifolia with Saccorhiza polyschides, Asparagopsis armata, and Ulva rigida; i, Pseudopolyides furcellaroides with C. baccata.

Dasya sessilis, Dasysiphonia japonica, Neosiphonia harveyi, Colpomenia peregrina. Cystoseira baccata and C. usneoides harbor most of the non-native species (10 and 11 species) followed by C. tamariscifolia (7 species). Some small and epiphytic species like $A$. ternifolia, Colpomenia peregrina, Falkenbergia rufolanosa or Neosiphonia harveyi can be mixture with typical epiphytes of Cystoseira spp., but other big and invasive species (Sargassum muticum) can disturb the habitat by occupying the substrata and shading the Cystoseira canopy as it was observed in Arenas \& al. (1995) and Sánchez \& Fernández (2005). Similar number of nonnative species were found the revision of the European maerl beds (Peña \& al., 2014) so the non-native species represent an important part of the associate flora of both maërl and Cystoseira assemblages, but more important is that the nonnative species can cover more extensive part of substrata more than the native ones.

\section{DISTURBANCES IN THE CYSTOSEIRA ASSEMBLAGES}

In the literature (Belegratis \& al., 1999; Sales \& al., 2011; Sales \& Ballesteros, 2012; Templado \& al., 2012) is reported that assemblages of Cystoseira have regressed considerably during the last decades in several Mediterranean localities, a fact attributed mainly to the negative impact of pollution and other anthropogenic pressures in the most of species of the genus Cystoseira. Moreover, five Cystoseira taxa
(C. amentacea, C. mediterranea, C. sedoides, C. spinosa, and C. zosteroides) are currently listed as species strictly protected under the Berne Convention (Annex I, 1979) and all the Mediterranean species of the genus Cystoseira, except C. compressa, have been listed under Annex II of the Barcelona convention (2010). Moreover, all the Mediterranean Cystoseira species are under surveillance by international organizations such as the IUCN, the RAC/ASP and MedPan (Thibaut \& al., 2014). Monitoring studies generally suggest pollution as the main factor influencing the disappearance of Cystoseira spp., however, there are not much studies providing experimental evidences for the disappearance of Cystoseira species related to pollution. Belegratis \& al. (1999) pointed out that one of the most negative effects is the eutrophication, as high nutrient levels trigger growth of epiphytes and phytoplankton, that concurrently inhibiting host growth through shading and, as a consequence, hostepiphyte complexes ultimately decline and are replaced by phytoplankton dominated systems. However, other factors like inorganic chemical pollution increased turbidity levels, overgrazing and climate change could be other possible causes (Sales \& Ballesteros, 2009). In addition, their data shows a positive relationship of rich and well developed Cystoseira assemblages to urbanization distance and low levels of nutrient concentration (Sales \& Ballesteros, 2009) and the results of the study of Sales \& al. (2011) suggest that heavy metal pollution could be negatively affecting survival and growth of Cystoseira species with species-specific responses. 
In their study, individuals of three Cystoseira species were transplanted from non-polluted to slightly polluted and heavily polluted areas, in places known to have Cystoseira spp. populations before pollution increased one century ago. Effects of pollution were species-specific: negative effects in survival of $C$. barbata and growth of $C$. crinita were detected in specimens transplanted to the high polluted area. The pollution could have been the cause that led to the disappearance of Cystoseira species in the past; however, neither survival nor growth of any of the Cystoseira species was negatively affected at the slightly polluted area, and growth was favored for C. barbata (Sales \& al., 2011).

Although great efforts are directed in the EU to improve water quality by the implementation of the Water Framework Directive and Cystoseira species are used as indicators of good water quality, no recovery of Cystoseira populations after improvement of water quality has been detected. Therefore, some authors (Belegratis \& al., 1999; Sales \& al., 2011; Bermejo \& al., 2012; Sales \& Ballesteros, 2012; Templado \& al., 2012) claim for alternative management of measures that facilitates the re-establishment of Cystoseira populations in areas where water quality has improved. In the Balearic Island, Sales \& Ballesteros (2007) found nine taxa of Cystoseira, some of them widely distributed around the island but other ones scarcely spread. Although these differences are probably due to physical causes more than pollution or anthropogenic disturbances, as sheltered Cystoseira assemblages are strongly determined by geomorphological features of the coast, Sales \& Ballesteros (2007) proposed to used Cystoseira assemblages as ecological indicators in biological monitoring for water quality assessment according to the EEC Water Framework Directive since they are very good indicators.

Because of the sedentary condition of attached microalgae that integrates the effects of long-term exposure to nutrients and/or other pollutants, the use of these benthic organisms as bioindicators to assess pollution values in the marine environment was proved successful in many ecological studies (Gorostiaga \& Díez, 1996; Díez \& al., 1999; Bermejo \& al., 2012; Santolaria, 2014). As macroalgal communities provide habitat and harbor for a wide variety of organisms, changes in these communities will have significant effects on shore ecosystems (Bermejo \& al., 2012). Hernández \& al. (2011) studied the vegetation in the intertidal zone of the port of Tarifa, (South Iberia). Some of the species were found in the catalogue of endangered species and can be used as bioindicators and should have a special attention, so recently the Cystoseira species have been included in the list of endangered species of the Mediterranean (Hernández \& al., 2011).

In Northeastern Atlantic Iberia was detected regression of the Cystoseira assemblages (Gorostiaga \& Díez, 1996; Díez, 1997; Díez \& al., 2009; Santolaria, 2014) pointed out that, the Cystoseira species are sensitive to contamination, as C. baccata and C. tamariscifolia were not present in polluted areas. Gorostiaga \& Díez (1996) found that in these unstable environments the community responds by simplifying its structure: reducing the number of layers, reducing vegetal cover and allowing a proliferation of opportunistic species with simple morphology, especially ceramiaceous algae. There is also proliferation of sciaphilous and sedimentation-resistant species. The crustose layer, made up of species having these characteristics, shows strong development in polluted environments. Díez \& al. (2009) found that only the most degraded assemblages experienced a significant increase in algal cover, revealing that this structural community parameter is not relevant in distinguishing between moderately degraded and unaltered vegetation. These results suggest that a significant reduction in algal cover takes place when a threshold of pollution intensity is exceeded. Likewise, the degree of water motion, depth, salinity and the nature of the pollution discharged seem to play major roles in algal cover response. The conclusion of this study is that following pollution abatement there was a partial recovery of intertidal phytobenthic assemblages. Intertidal vegetation at the degraded sites has become progressively more similar to that of the reference site, characterizing five succession stages. The Cystoseira species only appears in the last recovery stages, the reference stage, so the first sign of degradation of natural communities is the loss of large perennial macrophytes as Cystoseira. In this way, Santolaria (2014) pointed out that where the contamination were worse, the macrophytes as Cystoseira spp. were absent and replaced by caespitose algae as Gelidium pusillum and Caulacanthus ustulatus; however, with the progressive recovery of the water quality, the Cystoseira species appear again, so it would indicate the full biological recuperation of the station.

The biological invasions is another disturbance in the Cystoseira assemblages, as in marine ecosystems they have been increasing all around the world, mainly due to human activities such as international shipping, aquaculture and aquarium activity. The brown macroalgae Sargassum muticum, native to East Asia, is considered an invasive species around the world, being distributed mainly in sheltered or semi-exposed rocky shores, and regularly invades the habitats of algal species from the genus Cystoseira (Vaz-Pinto \& al., 2014). Previous studies (Sánchez \& Fernández, 2005; Olabarria \& al., 2009) showed the impact of the invasive Sargassum muticum on native assemblages, with a limited impact on native assemblages in northern Spain. Native species of Cystoseira can be displaced by Sargassum muticum (Critchley \& al., 1986; Viejo, 1997; Engelen \& Santos, 2009) and it causes changes in the structure of the native communities (Britton-Simmons, 2014). This could be explained because, although Sargassum muticum has a small basal disc, its bigger branches outshine the basal strata and compete for light and nutrients (Critchley \& al., 1986; Viejo, 1997; Britton-Simmons, 2004; Sánchez \& Fernández, 2005). Furthermore, the normal growth of Sargassum results in higher growth rates during shorter periods of time than those of Cystoseira (Rico \& Fernández, 1997) and the productivity is higher than in native species as C. baccata or Saccorbiza polyschides (Fernández \& al., 1990). In southwestern Portugal, Engel \& Santos (2009) found out that the progression of the Sargassum muticum invasion modulates the environment to its own requirements and the combination of K-selected traits and an increase in population growth rate when Sargassum muticum became more dominant suggested that competition with the native species C. humilis was an important biotic filter for the establishment phase of Sargassum muticum invasion. However, Arenas \& al. (1995) suggested that reproductive investment was higher in $C$. nodicaulis, so the successful colonization of Sargassum muticum in northern Spain shores is likely to be 
due to the large production of embryos. In addition, VazPinto \& al. (2014) suggested a better nutritional strategy of C. bumilis than Sargassum muticum to cope with limiting nutrient conditions of intertidal rocky pools, contrary to the expectations. In conclusion, Sargassum muticum has little effect in the native communities that are poorly invaded (Viejo, 1997; Sánchez \& Fernández, 2005) but exhibits an important effect under high density and size of the nonnative species (Britton-Simmons, 2004).

Undaria pinnatifida, another non-native species, quickly colonizes the substrata and in some geographic areas is the dominant species, triggering decreasing in abundance of the native species. It is an opportunistic species with a high capacity to colonize new substrata, but, as it appears in empty spaces, it is not very competitive in natural and stable conditions (Eno \& al., 1997). In Galicia it appears in the C. baccata assemblage, having not important impact in the community (Cremades \& al., 2006).

The non-native species Codium fragile is affects the native species as Codium tomentosum because it is very competitive and aggressive. An empty space in the substrata due to exploitation or the damage of the habitats, make easier that Codium fragile colonizes the substrata, making changes in the benthic communities and affecting the sedimentation process (Harris \& Tyrrel, 2001; Levin \& al., 2002).

Apart from these invasive species, other non-native ones have been reported in the literature as canopy over rocks (Lomentaria bakodatensis) and epiphytes (Anotrichium furcellatum, Antithamnionella spirographidis, A. ternifolia, Asparagopsis armata (gametophyte and sporophyte), Dasya sessilis, Dasysiphonia japonica, Neosiphonia harveyi, and Colpomenia peregrina) in the Cystoseira assemblages.

\section{FUTURE RESEARCHES FOR THE CYSTOSEIRA ASSEMBLAGES IN THE NORTH ATLANTIC IBERIA}

Taking into account that there is not much known about Cystoseira communities in the Atlantic Iberian coast, especially in the North coasts, it will be necessary to study their assemblages in depth concerning the habitat, the structure, the diversity, the seasonally changes, disturbing effects, nonnative and invasive species, long term changes, protected areas, etc. At the present, the more urgent study will be making an extensive research about $C$. baccata in Northern Iberia, as it is an exclusive Atlantic species that is widely distributed along the coast it is very little known about how its communities work, although it plays a key role structuring the communities. Furthermore, it is accompanied by the highest number of species and it has the highest number of epiphytes. In addition, C. baccata inhabits together with other four Cystoseira species so while studying the C. baccata communities we will obtain information of more species of Cystoseira. The necessity of making a study the Cystoseira communities in the North Atlantic Iberian coasts could be noticed reading Templado \& al. (2012), since they stablish that, in general, the Cystoseira species play an accompanied role, while in the literature the Cystoseira assemblages exhibit an important role in the North Atlantic Iberian coasts communities, more than only escort species. What is more, Templado \& al. (2012) only mentioned C. baccata in a sole paragraph as a species that sometimes appear in the Gelidium corneum communities. However, C. baccata is one of the most important species and widely distributed one in the North Atlantic Iberian coasts, developing their own communities, which have the highest diversity in the Cystoseira communities in these coasts. In addition, there are a several biological invasions that disturb the habitat by occupying the substrata and shading the Cystoseira canopy (Arenas \& al., 1995; Sánchez \& Fernández, 2005), so it is importante to know the distribution of non-native species and their impacts, especially in Galicia as some rías are important hotspot of introduced marine species (Bárbara \& al., 2008).

\section{REFERENCES}

Agardh, C.A. 1820. Species Algarum, 1. Lund, Greifswald.

Anadón, R., Gili, C., Guasch, E., Olivella, I., Polo, L. \& Ros, J. 1979. Distribución del poblamiento bentónico en una zona intermareal de la costa cantábrica gallega. Primer Simposio de Bentos: 673-710.

Araújo, R., Bárbara, I., Sousa-Pinto, I. \& Quintino, V. 2005. Spatial variability of intertidal rocky shore assemblages in the northwest coast of Portugal. Estuarine costal and Shelf Science 64: 658-670.

Araújo, R., Sousa-Pinto, I., Bárbara, I. \& Quintino, V. 2006. Macroalgal communities of intertidal rock pools in the northwest coast of Portugal. Acta Oecologica 30: 192-202.

Ardré, F. 1970. Contribution a l'étude des algues marines du Portugal. I. La Flore. Portugaliae Acta Biologica 10(1-4): 1-375.

Arenas, F., Fernández, C., Rico, J. M., Fernández, E. \& Haya, D. 1995. Growth and reproductive strategies of Sargassum muticum (Yendo) Fensholt and Cystoseira nodicaulis (Whit.) Roberts. Scientia Marina 59(1): $1-8$.

Arrontes, J. 1990. Composition, distribution on host, and seasonality of epiphytes on three intertidal algae. Botanica Marina 33: 205-211.

Ballesteros, E. 1988. Estructura y dinámica de la comunidad de Cystoseira mediterranea Sauvageau en el Mediterráneo noroccidental. Investigación Pesquera 52(3): 313-334.

Ballesteros, E. 1989. Production of seaweeds in Northwestern Mediterranean marine communities: Its relation with environmental factors. Scientia Marina 53(2-3): 357-364.

Ballesteros, E. 1990a. Structure and dynamics of the Cystoseira caespitosa Sauvageau (Fucales, Phaeophyceae) community in the North-Western Mediterranean. Scientia marina 54(2): 155-168.

Ballesteros, E. 1990b. Structure and dynamics of the community of Cystoseira zosteroides (Turner) C. Agardh (Fucales, Phaeophyceae) in the northwestern Mediterranean. Scientia marina 54(3): 217-229.

Ballesteros, E., Sala, E., Garrabou, J. \& Zabala, M. 1998. Community structure and frond size distribution of a Deep water stand of Cystoseira spinosa (Phaeophyta) in the Northwestern Mediterranean. European Journal of Phycology 33: 121-128.

Bárbara, I. 1994. Las comunidades de algas bentónicas marinas en la babia de La Coruña y ría del Burgo. Tesis doctoral en microfichas n. ${ }^{0} 357$. Servicio de Publicaciones e Intercambio Científico de la Universidad de Santiago de Compostela, Santiago de Compostela.

Bárbara, I. \& Cremades, J. 1987. Guía de las algas del litoral gallego. Ayuntamiento de La Coruña, A Coruña.

Bárbara, I., Cremades, J. \& Pérez-Cirera, J. L. 1995. Zonación de la vegetación bentónica marina en la Ría de A Coruña (N.O. de España). Nova Acta Científica Compostelana (Bioloxía) 5: 5-23.

Bárbara, I., Lee, S.-Y., Peña, V., Díaz, P., Cremades, J., Oak, J.H. \& Choi, H.-G. 2008. Chrysymenia wrightii (Rhodymeniales, Rhodophyta) a new non-native species for the European Atlantic Coast. Aquatic Invasions 3(4): 367-375.

Bárbara, I., Gallardo, T., Cremades, J., Barreiro, R., Maneiro, I. \& Saunders, G.W. 2013. Pseudopolyides furcellarioides gen. et sp. nov. (Gigartinales, Rhodophyta) an erect member of the Cruoriaceae based on morphological and molecular evidence. Phycologia 52(2): 191-203.

Barceló i Martí, M.C. \& Seoane Camba, J.A. 1984. Nota sobre la variación fenológica de Cystoseira sauvageauana Hamel en las costas de Alicante. Anales de Biología 2(2): 45-54.

Belegratis, M.R., Bitis, I., Economou-Amilli, A. \& Ott, J.A. 1999. Epiphytic patterns of macroalgal assemblages on Cystoseira species (Fucales, Phaeophyta) in the east coast of Attica (Aegean Sea, Greece). Hydrobiologia 412: 67-80. 
Bermejo, R. 2014. Using seaweed assemblages on intertidal rocky shores to assess the ecological status of Andalusian coasts. Biogeographical implications. Tesis doctoral. Universidad de Cádiz, Puerto Real.

Bermejo, R., Vergara, J.J. \& Hernández, I. 2012. Application and reassessment of the reduced species list index for macroalgae to assess the ecological status under the Water Framework Directive in the Atlantic coast of Southern Spain. Ecological indicators 12: 46-57.

Britton-Simmons, K.H. 2004. Direct and indirect effects of the introduced alga Sargassum muticum on benthic, subtidal communities of Washington State, USA. Marine Ecology Progress Series 277: 61-78.

Cormaci, M., Furnari, G., Giaccone, G. \& Serio, D. 1990. Taxonomic and biogeographic observations on some species of the genus Cystoseira: C. sauvageauana, C. barbatula and C. pelagosae. Rapports Commision International Mer Méditerranée 32(1): 314.

Cormaci, M., Furnari, G., Catra, M., Alongi, G. \& Giaccone, G. 2012. Flora marina bentónica del Mediterraneo: Phaeophyceae. Bollettino Accademia Gioenia Scientia Naturale 45(375): 1-508.

Cremades, J., Bárbara, I. \& Veiga, A.J. 1998. Las Macroalgas Marinas y sus Aplicaciones. Fondo de Formación, Ferrol.

Cremades, J., Bárbara, I. \& Veiga, A.J. 2004. Intertidal vegetation and its commercial potential on the shores of Galicia (NW Iberian Peninsula). Thalassas 20(2): 69-80.

Cremades Ugarte, J., Freire Gago, O. \& Peteiro García, O. 2006. Biología, distribución e integración del alga alóctona Undaria pinnatifida (Laminariales, Phaeophyta) en las comunidades bentónicas de las costas de Galicia (N.O. Península Ibérica). Anales del Jardín Botánico Madrid 63(2): 169-187.

Critchley, A.T., Farnham, W.F. \& Morrell, S.L. 1986. An account of the attempted control of an introduced marine alga, Sargassum muticum, in Southern England. Biological Conservation 35: 313-332.

Díaz Tapia, P., Bárbara, I. \& Barreiro, R. 2011. Iberian intertidal turf assemblages dominated by Erythroglossum lusitanicum (Ceramiales, Rhodophyta): structure, temporal dynamics and phenology. Botanica Marina 54: 507-521.

Díaz Tapia, P., Bárbara, I. \& Díez, I. 2013. Multi-scale spatial variability in intertidal benthic assemblages: differences between sand-free and sandcovered rocky hábitats. Estuarine, Coastal and Shelf Science 133: 97-108.

Díez, I. 1997. Vegetación bentónica marina como indicador ecológico de la calidad de las aguas: Abra de Bilbao y costa adyacente. Tesis doctoral. Universidad del País Vasco, Leioa.

Díez, I., Secilla, A., Santolaria, A. \& Gorostiaga, J.M. 1999. Phytobenthic intertidal community structure along an environmental pollution gradient. Marine Pollution Bulletin 38: 463-472.

Díez, I., Santolaria, A., Secilla, A. \& Gorostiaga, J.M. 2009. Recovery stages over long-term monitoring of the intertidal vegetation in the "Abra de Bilbao" area and on the adjacent coast (N. Spain). European Journal of Phycology 1(14): 1-14.

Draisma, S.F., Ballesteros, E., Rosseau, F. \& Thibaut, T. 2010. DNA sequence data demonstrate the polyphily of the genus Cystoseira and other Sargassaceae genera (Phaeophyceae). Journal Phycological 46: $1329-1345$.

Engelen, A. \& Santos, R. 2009. Which demographic traits determine population growth in the invasive brown seaweed Sargassum muticum? Journal of Ecology 97: 675-684.

Eno, N.C., Clarck, R.A. \& Sanderson, W.G. 1997. Non-native marine species in British waters: a review and directory. Joint Nature Conservation Committee, Peterborough.

Feldmann, J. 1937. Recherches sur la végétation marine de la Méditerranée. La Côte des Albères. Les Cyanophycées, Chlorophycées et Phéophycées de la Côte des Albères. Tesis doctoral. Faculté des sciences de L'Université de Paris, Paris.

Fernández, C. \& Niell, F.X. 1981. Distribución espacial del fitobentos en los horizontes inferiores del sistema intermareal rocoso de cabo Peñas (Asturias). Investigaciones pesqueras 45(2): 309-326.

Fernández, C. \& Niell, F.X. 1982. Zonación del fitobentos intermareal de la región de Cabo Peñas (Asturias). Investigaciones pesqueras 46 (1): 121-141.

Fernández, C., Gutiérrez, L.M. \& Rico, J.M. 1990. Ecology of Sargassum muticum on the north coast of Spain. Preliminary observations. Botanica marina 33: 423-428.

Fritsch, F.E. 1981. The structure and reproduction of the algae. Volume II. Foreword, Phaeophycea, Rhodophyceae, Myxophyceae. Cambridge University Press, Cambridge.

Furnari, G. 1997. Progress in the study of Mediterranean communities with Cystoseira spp. (Phaeophyta, Fucales). XII Simposio de Botanica Criptogámica: 1-9.
Furnari, G., Cormaci, M. \& Alongi, G. 1999. Lectotypification of Cystoseira algerensis J. Feldmann and Cystoseira elegans Sauvageau (Cystoseiracea, Phaeophyta). Cryptogamie, Algologie 20(1): 19-23.

Garbary, D. 1976. Life-forms of Algae and their distribution. Botanica marina 19: 97-106.

Gili, C., Anadón, R., Carbonell, J., Olivella, I. \& Ros, J. 1979. Comunidades bentónicas submarinas del litoral de Lugo. I. Resultados preliminares. Primer Simposio de Bentos: 711-747.

Gómez Garreta, A., Barceló Martí, M.C., Gallardo García, T., Pérez-Ruzafa, I.M., Ribera Sigual, M.A. \& Rull Lluch, J. 2000. Flora Phycologica Iberica. Vol. 1. Fucales. Universidad de Murcia. Murcia.

Gorostiaga, J.M. 1995. Sublittoral seaweed vegetation of a very exposed shore on the Basque Coast (N. Spain). Botanica marina 38: 9-16.

Gorostiaga, J.M. \& Díez, I. 1996. Changes in the subtidal benthic marine macroalgae in the polluted area of Abra de Bilbao and proximal coast (Northern Spain). Marine Ecology Progress Series 130: 157-167.

Gorostiaga, J.M., Santolaria, A., Secilla, A. \& Díez, I. 1998. Sublittoral benthic vegetation of the eastern Basque coast (N. Spain): structure and environmental factors. Botanica Marina 41: 455-465.

Granja, A., Cremades J. \& Bárbara I. 1992. Catálogo de las algas bentónicas marinas de la Ría de Ferrol (Galicia, N.O. de la Península Ibérica) y consideraciones biogeográficas sobre su flora. Nova Acta Cientifica Compostelana (Bioloxía) 3:3-21.

Guiry, M.D. \& Guiry, G.M. 2014. AlgaeBase. World-wide electronic publication, National University of Ireland, Galway. http://www.algaebase.org.

Hardy-Halos, M.T., Castric-Fey, A., Girard-Descatoire, A. \& Lafargue, F. 1973. Recherches en scaphandre autonome sur le peuplement végétal du substrat rocheux: l'Archipel de Glénan. Bulletin de la Société Scientifique de Bretagne 48: 103-128.

Harris, L. G. \& Tyrrell, M.G. 2001. Changing community states in the Gulf of Maine: synergism between invaders, overfishing and climate change. Biological Invasions 3: 9-21.

Hernández, I., Bermejo, R., Vergara, J.J., Olivé, I., Brun, F.G., Mourente, G., Santos, C.B. \& Pérez-Lloréns, J.L. 2011. Estudio ficológico del intermareal y fondos submareales del sector oriental del Parque Natural del Estrecho, entre el puerto de Tarifa y Piedra Alta. MIGRES 2: 1-10.

Levin, P.S., Coyer, J.A., Petrik, R. \& Good, T.P. 2002. Community-Wide effects of nonindigenous species on temperate rocky reefs. Ecology 83 (11): 3182-3193.

Littler, M.M. \& Littler, D.S. 1984. Relationships between macroalgal functional form groups and substrata stability in a subtropical rocky-intertidal system. Journal of Experimental Marine Biology and Ecology 74: 13-34.

Llera González, E. \& Álvarez Raboso, J. 2007. Algas marinas de Asturias. Consejería de Medio Ambiente, Oviedo.

Miranda, F. 1931. Sobre las algas y cianofíceas del cantábrico especialmente de Gijón. Trabajos del Museo Nacional de Ciencias Naturales. Serie Botánica 25: 5-106.

Montesanto, B. \& Panayotidis, P. 2001. The Cystoseira spp. communities from the Aegean Sea (NE Mediterranean). Mediterranean Marine Science 2(1): 57-67.

Morales-Ayala, S. \& Viera-Rodríguez, M.A. 1989. Distribución de los epífitos en Cystoseira tamariscifolia (Hudson) Papenfuss (Fucales, Phaeophyta) en punta de Gáldar (Gran Canaria, Islas Canarias). Anales del Jardín Botánico de Madrid 46(1): 107-113.

Olabarria, C., Rodil, I.F., Incera, M. \& Troncoso J.S. 2009. Limited impact of Sargassum muticum on native algal assemblages from rocky intertidal shores. Marine Environmental Research 67: 153-158.

Oliveras Plá, M.A. \& Gómez Garreta, A. 1999. Corología del género Cystoseira C. Agardh (Phaeophyceae, Fucales). Anales del Jardín Botánico de Madrid 46(1): 89-97.

Otero-Schmitt, J. 1993. Estudio de la fitocenosis bentónicas litorales en el tramo de costa comprendido entre Pta. Louro y Pta. Remedios (La CoruñaEspaña). Tesis doctoral. Universidad de Santiago de Compostela, Santiago de Compostela.

Otero-Schmitt, J. \& Pérez-Cirera, J.L. 1996. Epiphytism on Cystoseira (Fucales, Phaeophyta) from the Atlantic Coast of Northwest Spain. Botanica Marina 39: 445-465.

Otero-Schmitt, J. \& Pérez-Cirera, J.L. 2002. Infralittoral benthic biocoenoses from Northern Ría de Muros, Atlantic coast of Northwest Spain. Botanica Marina 45: 93-122.

Otero-Schmitt, J., Comesaña, P. \& Castro, M. 2002. Guía das Macroalgas de Galicia. Baía, A Coruña.

Pardi, G., Piazzi, L. \& Cinelli, F. 2000. Demographic study of a Cystoseira bumilis Kützing (Fucales: Cystoseiraceae) population in the western mediterranean. Botanica Marina 43: 81-86. 
Peña, V. \& Bárbara, I. 2006. Los fondos marinos de maërl del Parque Nacional de las Islas Atlánticas (Galicia, España): distribución, abundancia y flora asociada. Nova Acta Científica Compostelana 15: 7-25.

Peña, V., Bárbara, I., Grall, J., Maggs, V. \& Hall-Spencer, J.M. 2014. The diversity of seaweeds on maerl in the NE Atlantic. Marine Biodiversity 44(4): 533-551.

Ribera, M.A., Gómez Garreta, A., Gallardo, T., Cormaci, M., Furnari, G. \& Giaccone, G. 1992. Check-list of Mediterranean Seaweeds. Botanica Marina 35: 109-130.

Rico, J.M. \& Fernández, C. 1997. Ecology of Sargassum muticum on the North coast of Spain. II. Physiological differences between Sargassum muticum and Cystoseira nodicaulis. Botanica Marina 40: 405-410.

Roberts, M. 1967. Studies on marine algae of the British Isles. 3. The genus Cystoseira. British Phycological Bulletin 3(2): 345-366.

Rodríguez-Prieto, C., Ballesteros, E., Boisset, F. \& Alfonso-Carrillo, J. 2013. Guía de las Macroalgas y Fanerógamas marinas del Mediterráneo occidental. Omega, Barcelona.

Rull Lluch, J. \& Gómez Garreta, A. 1989. Distribución de las algas epífitas sobre los ejemplares de Cystoseira mediterranea Sauv. Anales del Jardín Botánico Madrid 46(1): 99-106.

Sales, M. \& Ballesteros, E. 2007. Shallow, sheltered water populations of Cystoseira sp. in Menorca (Balearic Islands). Actes du $3^{\text {eme }}$ Symposium méditerranéen sur la végétation marine: 164-171.

Sales, M. \& Ballesteros, E. 2009. Shallow Cystoseira (Fucales, Ochrophyta) assemblages thriving in sheltered areas from Menorca (NW Mediterranean): Relationships with environmental factors and anthropogenic pressures. Estuarine, Coastal and Shelf Science 84: 476-482.

Sales, M. \& Ballesteros, E. 2012. Seasonal dynamics and anual production of Cystoseira crinita (Fucales, Ochrophyta)-dominated assemblages from the northwestern Mediterranean. Scientia Marina 76(2): 391-401.

Sales, M., Ballesteros, E., Anderson, M.J., Ivesa, L. \& Cardona, E. 2012. Biogeographical patterns of algal communities in the Mediterranean
Sea: Cystoseira crinita-dominated assemblages as a case study. Journal of Biogeography 39: 140-152.

Sales, M., Cebrian, E., Tomas, F. \& Ballesteros, E. 2011. Pollution imapcts and recovery potential in three species of the genus Cystoseira (Fucales, Heterokontophyta). Estuarine, Coastal and Shelf Science 92: 347-357.

Sánchez, I. \& Fernández, C. 2005. Impact of the invasive seawwed Sargassum muticum (Phaeophyta) on an intertidal macroalgal assemblage. Journal of Phycology 41: 923-930.

Santolaria, A. 2014. Dinámica del macrofitobentos marino de sustrato duro en un área portuaria en proceso de recuperación ambiental. Tesis doctoral. Universidad del País Vasco, Leioa.

Steneck, R.S. \& Dethier, M.N. 1994. A functional group approach to the structure of algal dominated communities. Oikos 69: 476-498.

Templado, J., Ballesteros, E., Galparsoro, I., Borja, A., Serrano, A., Marín, L. \& Brito, A. 2012. Inventario español de bábitats y especies marinos. Guía interpretativa: inventario español de bábitats marinos. Ministerio de Agricultura, Alimentación y Medio Ambiente, Madrid.

Thibaut. T., Blanfuné, A., Markovic, L., Verlaque, M., Boudouresque, C.F., Perret-Boudouresque, M., Mácic, V. \& Bottin, L. 2014. Unexpected abundance and long-term relative stability of the Brown alga Cystoseira amentacea, hitherto regarded as a threatened species, in the north-western Mediterranean Sea. Marine Pollution Bulletin 89(1-2): 305-323.

Vaz-Pinto, F., Martínez, B., Olabarria, C. \& Arenas, F. 2014. Neighbourhood competition in coexisting species: The native Cystoseira bumilis vs. the invasive Sargassum muticum. Journal of Experimental Marine Biology and Ecology 454: 32-41.

Viejo, R.M. 1997. The effects of colonization by Sargassum muticum on tidepool macroalgal assemblages. Journal of the Marine Biological Association of the United Kingdom 77: 325-340.

Associate Editor: A. Flores Received: 16-II-2015 Acepted: 10-X-2015 